Inter-American Development Bank

Competitiveness and Innovation Division (IFD/CTI)

DISCUSSION PAPER

Innovation and No. IDB-DP-263

\title{
Productivity in Services: Evidence from Chile
}

Roberto Álvarez

Andrés Zahler

Claudio Bravo-Ortega 


\title{
Innovation and Productivity in Services: Evidence from Chile
}

\author{
Roberto Álvarez \\ Andrés Zahler \\ Claudio Bravo-Ortega
}

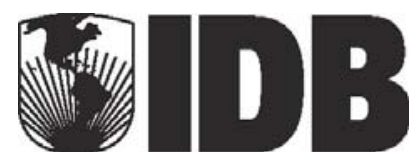

Inter-American Development Bank 2012 
http://www.iadb.org

The opinions expressed in this publication are those of the authors and do not necessarily reflect the views of the Inter-American Development Bank, its Board of Directors, or the countries they represent.

The unauthorized commercial use of Bank documents is prohibited and may be punishable under the Bank's policies and/or applicable laws.

Copyright @ 2012 Inter-American Development Bank. All rights reserved; may be freely reproduced for any non-commercial purpose.

Roberto Álvarez: robalvar@fen.uchile.cl; Andrés Zahler: andres.zahler@udp.cl; Claudio Bravo-Ortega: clbravo@fen.uchile.cl 


\title{
Innovation and Productivity in Services Evidence from Chile
}

\author{
Roberto Álvarez \\ robalvar@fen.uchile.cl \\ Intelis, University of Chile
}

\author{
Andrés Zahler \\ andres.zahler@udp.cl \\ Intelis and Diego Portales University
}

\author{
Claudio Bravo-Ortega \\ clbravo@fen.uchile.cl \\ Intelis, University of Chile
}

\begin{abstract}
*
This paper analyzes empirically the relationship between innovation and productivity in the Chilean services sector. Consistent with recent evidence on developed countries, we find that services firms are as innovative as firms in the manufacturing industry. In the basic model, we also find that both industries have similar determinants of the investment in innovation and the probability of introducing innovations (products or process), such as size and export status. In several extensions we find similar roles for technological and non-technological innovation in labor productivity and for determinants such as skill intensity and financial restrictions. In general, our evidence suggests that that innovation input and output is associated with improvements in productivity in both sectors. Since we do not find clear-cut differences, it might be the case that even larger efforts need to be done to have better measures of innovation and productivity in the services industries.
\end{abstract}

JEL Classification: O31, O33, L80

Keywords: Productivity, innovation, services

\footnotetext{
* We thank attendants of the seminars at INTELIS, University of Chile for their valuable comments and suggestions, and Matias Caamaño and Rolando Campusano for their invaluable research assistance. We also thank the IDB, IDRC and the Millennium Science Initiative (Project NS 100017 "Centro Intelis”) for their financial support.
} 


\section{Introduction}

There is an increasing consensus that the key for long run prosperity in economies stems from productivity growth. This is particularly true in Latin America, where the productivity gap appears to be the most important explanation of why the region is lagging behind not only the developed countries, but other similar countries that have been able to develop in the last 50 years (Daude and Fernández-Arias, 2010; IDB, 2010).

A fundamental ingredient of this poor performance may be the evolution of the services sector. Most of the region has partly skipped a process of industrialization before becoming a "services economy", by directly shifting resources from agriculture into services. Thus, today most Latin-American economies' GDP and employment is overwhelmingly driven by the Services sector. In the same direction, the low productivity in the services sector seems to explain an important part of the income and productivity lag of the region (IDB, 2010). Thus, a study of the determinants and constraints for innovation and productivity growth in this sector seems urgent and relevant from a policy point of view.

Despite the diagnosis discussed above, until very recently the service sector has been unexplored, or directly neglected, as an object of analysis in terms of its role in productivity growth and as a source and driver of innovation in economies. It was usually presumed that services, despite increasing its share in GDP and employment as countries develop, was not an innovative sector and just used technologies developed elsewhere (Tether and Howells, 2007; Gallouj and Savona, 2009). Tether (2005) indicates that there are two main traditions in the literature about innovation in services. The first one is the denominated "assimilation approach" that considers that innovation in services is similar to innovation in manufacturing. The second one is the called "demarcation approach" contending that innovation in services is highly different than innovation in manufacturing. This approach implicates that new theories and measurements are needed to understand innovation better in the services industry. More recently, according to Tether (2005), a new perspective has flourished. This is the "synthesis approach" arguing that both sectors do not follow completely different innovation paths, but it is necessary to acknowledge that there are some differences in terms of innovation activities pursued in both sectors and how they need to be measured and understood. 
Recent evidence on innovation in services from developed economies and some (still scarce) from developing countries suggests that the services sector is as innovative as the manufacturing sector. ${ }^{1}$ Indeed, part of this sector is also significantly tradable and subject to the potential benefits coming from international competition. Tether (2005), using information for several European countries, finds that services firms in fact do innovate, although the propensity to innovate technologically is lower than manufacturing firms. He finds some differences in the innovation orientation of services firms: they are more likely to innovate in organization change than firms in the manufacturing industry. However, he concludes that there is not a unique pattern of innovation among firms in this sector. ${ }^{2}$

A significant amount of recent research also has shown that the services sector is much more heterogeneous than manufacturing or the primary sector and that the way innovation occurs is in many ways different from traditional technological innovation. This has been increasingly captured by innovation surveys across the world by including this diversity in the samples and by expanding questionnaires to include issues of "soft" or non-technological innovation $^{3}$. Sirilli and Evangelista (1998) analyze major similarities and differences of services innovation compared with manufacturing. They find a high heterogeneity in technological innovation among sector in the services industry. Interestingly, the evidence shows that innovation expenditure per employee in services is very close to the manufacturing average. They conclude that service and manufacturing sectors show more similarities than differences regarding basic dimensions of the innovation process. Following this literature, in this paper we show evidence for both industries and highlight the main differences and similarities between them.

Analyzing the determinants of innovation and its relation with productivity is particularly relevant in the services sector. It is a novel and relevant research, which shed light on some of the causes of the existence or lack of productivity of this sector, with its particularities. It will also enlighten the discussion of policy seeking to promote innovation in services, and how particular or specific should policy be compared to the support already given by default to other sectors of the economy through instruments focused on technological (or "hard") innovation. There is scarce previous empirical evidence on these issues. Leiponen

\footnotetext{
${ }^{1}$ See Iacovone et al (2012).

${ }^{2}$ See also Pires et al. (2008) and Santamaria et al. (2012)

${ }^{3}$ See Djellal and Gallouj (2001), Drejer (2004), and Tether et al. (2007), chapter 1.
} 
(2012) studies the determinants of innovation for Finish firms in manufacturing and service industries, focusing on the effects of $\mathrm{R} \& \mathrm{D}$ investments and breadth in knowledge sourcing and innovation objectives. He finds that $R \& D$ has a significant effect on innovation for both industries, but the breadth of innovation objectives seems to be detrimental for innovation in services. Cainelli et al. (2006), for Italy, explore the links between innovation and economic performance in services. They find a two-way relationship: innovation is positively affected by firm's past performance and innovation, particularly investment in ICT, has a positive impact on productivity and growth. In contrast, Gustavsson and Karpaty (2011), following the ideas of Aghion et al. (2005), focus on the relationship between competition and innovation in the Swedish services sector. They find evidence of an inverted U-shaped relation between innovation and competition. In this paper, following closely the model of Crepon et al. (2008), we explore these issues more deeply by studying jointly the determinants of innovation investment and innovation outcomes, and we look also at the impact of innovation on productivity ${ }^{4}$. We explore not only differences between manufacturing and services, but also between traditional services and KIBS.

In the case of Chile, an in depth analysis of these determinants is doubly interesting. On the one hand Chile has been carrying innovation surveys for a long period of time using the same methodologies as the state of the art surveys in developed economies ${ }^{5}$. Moreover, the four latest rounds of this survey have included the services sector at a one-digit ISIC rev 3 level. Chile has also carried two larger surveys (the Encuesta Longitudinal de Empresas ELE), which will also be used in the analysis.

On the other hand, as previously noted, recent economic and case studies have indicated that several Services subsectors are highly innovative and have expanded abroad through exports and foreign direct investment. This dynamism might partly explain the relative good performance of aggregate productivity in services relative to other Latin American countries (IADB 2011), and provides a great deal of heterogeneity at the micro level to be exploited.

Our main objectives are the following: (i) to investigate the relationship among innovation inputs, outputs, and productivity for the services sector in Chile, (ii) to identify and

\footnotetext{
${ }^{4}$ See Vahter and Masso (2011) for a similar analysis in Estonia's service sector.

${ }^{5}$ Using as a basis the Oslo manual. See OECD (2005).
} 
reconfirm the similarity and differences in the innovative activity and its determinants in the service sector compared to manufacturing, (iii) to identify some of the main obstacles to innovation, in special financial constraints, and to analyze how they impact in the probability of innovating, (iv) to analyze what factors enhance the probability of innovating and spending in innovation in a causal sense and compare them with the drivers in the manufacturing sector, and (v) to investigate the role of different types of innovation in productivity and the particular role of $\mathrm{R} \& \mathrm{D}$.

This paper is structured in the following way. In the second section, we describe the data and we show some comparative analysis between manufacturing and service firms. In section 3, we explain the methodology, which is mainly based on Crepon et al. (2008). In section 4, we show the results of the basic model. In section 5, we present results for several extensions to the basic model. The conclusions are presented in section 6 .

\section{Data and Descriptive Statistics}

We benefit from a wide number of innovations surveys, which have been conducted in the last decade. In total 7 innovation surveys have been conducted. However only the last four surveys cover the services sector. Nevertheless, we will use only a pooled cross-section of $5^{\text {th }}$ and $6^{\text {th }}$ survey (which cover the years 2005-2006 and 2007-2008 respectively) for our base specifications, given that the questions of these two surveys are the most consistent through time $^{6}$. These surveys, with some small variation have maintained standardized questions according to the Oslo Manual, and thus can be used effectively for comparable estimations. The surveys include firms from other relevant sectors such as commodities, which we drop to focus our analysis in the services sector and manufacturing. ${ }^{7}$ We will also provide estimations using the Encuesta Longitudinal de Empresas (ELE). ${ }^{8}$

\footnotetext{
${ }^{6}$ We will provide our results for the base scenario without the use of weights. This is because we have missing values that require reweighting of the data. Nevertheless, in the extensions of the paper we show the results for the same pooled-cross section with the use of weights, as well as the results using the $4^{\text {th }}, 5^{\text {th }}, 6^{\text {th }}$ and $7^{\text {th }}$ pooled innovation surveys. We tried to build panels using pairs of surveys but the number of data points decreased dramatically since these surveys are not constructed with the goal of forming a panel. Also, the number of observations for each sector varies substantially from survey to survey. For those reasons we abandoned that data strategy.

${ }^{7}$ In the setup of our database we also drop plants that do not have data for our relevant estimations. In particular, some data points that do not declare sales or employment are dropped from each survey.

${ }^{8}$ ELE is a much larger firm level survey for the whole economy. There have been two rounds for this survey, ELE1
} 
The services sector (and the survey in general) is subdivided according to an ISIC rev.3 classification of economic activities. The surveys are taken at a disaggregation level of 1 digit. This implies that for the services sector we have 9 subsectors, where we define KIBS as sectors $\mathrm{K}$ and $\mathrm{I}$ (R\&D, transport, communication and real estate services $\left.{ }^{9}\right)$. The innovation surveys ask quantitative and qualitative questions about innovation inputs and outputs, both technological and non-technological, obstacles for doing innovation as well as sources for cooperation. Some key average descriptive characteristics and comparisons between sectors can be found in tables 1-6 below.

Tables 1 and 2 compare innovation outputs between different sectors. Looking first at aggregate propensities an issue that can be noted is that the service sector produces technological innovative output at a similar (slightly smaller) rate than the manufacturing sector particularly in product innovation, where the percentage of firms that have innovated is 22 percent in manufacturing and 21.3 percent in services. In process innovation the difference is larger (26 percent to 20.8 percent ) but still similar. These small differences in favor of manufacturing can also be seen in the total percentage of innovative firms, the percentage of firms that do in-house technological innovation and the percentage of innovations that are cutting edge (at least new to the domestic market). Also, process innovation seems relatively more prevalent in services than in manufacturing, where firms have a higher propensity to innovate in processes. With respect to non-technological innovation, services firms have a marginally higher propensity to innovate in organizational issues, but the opposite can be observed for marketing innovations, where there is a slight advantage of innovativeness of the manufacturing sector, contrary to conventional wisdom. In both sectors organizational innovations are much more common than marketing innovations. Overall both sectors have a very similar propensity to innovate in technological and/or non-technological innovations.

A more interesting and diverse picture emerges when we disaggregate the service sector into its still-very-heterogeneous subsectors. The most innovative subsector in the analysis is

and ELE2. We provide however results only for ELE1 Again, since this survey was not designed initially as a panel we do not have a match for a significant number of firms and for that reason we will not pursue the use of a panel. Also, ELE 2 unfortunately does not ask any questions regarding R\&D, which is an essential input to determine innovation expenditures.

${ }^{9}$ Unfortunately, the fact that INE provides a disaggregation for the service sector only at the 1 digit level makes it impossible to not consider a subsector such as real estate which is not considered a part of KIBS. 
sector $\mathrm{K}$, which encompasses business activities and R\&D. ${ }^{10}$ It is significantly more productive in product innovation than all other subsectors, including manufacturing. However, the Utilities sector (particularly in process innovation) and the Health and social services appear as also very innovative. The less innovative subsectors are retail and hotels and restaurants, which is consistent with the fact that these industries are usually of relatively low productivity. Regarding non-technological innovation, subsector $\mathrm{K}$ also highlights having a higher propensity to innovate than manufacturing. Here also Health services have very high propensities, being overall higher than the business services sector.

\footnotetext{
${ }^{10}$ The other sector that we incorporated under the definition of KIBS shows a lower propensity to innovate than many subsectors. It would have been great to include only the telecommunications subsector as part of KIBS. However, as already noted, this was impossible due to the 1-digit level of disaggregation of the $5^{\text {th }}$ and $6^{\text {th }}$ innovation surveys.
} 
Table 1.

\begin{tabular}{|c|c|c|c|c|c|c|c|c|c|c|c|c|}
\hline \multirow[t]{2}{*}{ Years 2005-2008 } & & & \multicolumn{5}{|c|}{ Technological Innovation } & \multicolumn{3}{|c|}{ Non-Technological Innovation } & \multirow[b]{2}{*}{$\begin{array}{l}\text { Any Innovation } \\
\text { (4) }\end{array}$} & \multirow[b]{2}{*}{$\begin{array}{c}\text { Tech and Non- } \\
\text { Tech Innovation } \\
\text { (5) } \\
\end{array}$} \\
\hline & $\mathrm{N}$ & CIIU & Product $(*)$ & Process & $\begin{array}{r}\text { Innovative } \\
\text { firms (1) }\end{array}$ & $\begin{array}{c}\text { In-house } \\
\text { Tech-Innov } \\
(* *)\end{array}$ & $\begin{array}{l}\text { New to Market } \\
(* * *)(2)\end{array}$ & Organization & Marketing & $\begin{array}{l}\text { Non-Tech } \\
\text { Innovation (3) }\end{array}$ & & \\
\hline \multirow[t]{2}{*}{ All Service Industry } & 4332 & & $21.3 \%$ & $20.8 \%$ & $28.4 \%$ & $23.3 \%$ & $10.4 \%$ & $26.6 \%$ & $12.8 \%$ & $27.8 \%$ & $35.2 \%$ & $21.1 \%$ \\
\hline & \multicolumn{12}{|c|}{ KIBS } \\
\hline $\begin{array}{l}\text { Real estate, renting and } \\
\text { business activities }\end{array}$ & 843 & $\mathrm{~K}$ & $31.3 \%$ & $25.9 \%$ & $36.5 \%$ & $25.7 \%$ & $19.0 \%$ & $29.8 \%$ & $17.9 \%$ & $32.4 \%$ & $41.8 \%$ & $27.2 \%$ \\
\hline $\begin{array}{l}\text { Transport, storage and } \\
\text { communications }\end{array}$ & 870 & I & $18.9 \%$ & $18.1 \%$ & $24.5 \%$ & $21.3 \%$ & $9.3 \%$ & $24.7 \%$ & $11.2 \%$ & $25.3 \%$ & $31.0 \%$ & $18.7 \%$ \\
\hline \multirow{2}{*}{ Subtotal } & 1713 & & $25.0 \%$ & $21.9 \%$ & $30.4 \%$ & $23.4 \%$ & $14.1 \%$ & $27.2 \%$ & $14.5 \%$ & $28.8 \%$ & $36.3 \%$ & $22.3 \%$ \\
\hline & \multicolumn{12}{|c|}{ Traditional Services } \\
\hline $\begin{array}{l}\text { Electricity, gas and water } \\
\text { supply }\end{array}$ & 212 & $\mathrm{E}$ & $13.2 \%$ & $32.1 \%$ & $34.0 \%$ & $34.2 \%$ & $7.6 \%$ & $29.7 \%$ & $5.7 \%$ & $29.7 \%$ & $43.9 \%$ & $19.8 \%$ \\
\hline Construction & 638 & $\mathrm{~F}$ & $18.8 \%$ & $23.0 \%$ & $29.2 \%$ & $22.3 \%$ & $8.2 \%$ & $28.1 \%$ & $8.5 \%$ & $29.5 \%$ & $36.2 \%$ & $22.4 \%$ \\
\hline $\begin{array}{l}\text { Wholesale and retail trade } \\
\text { and reparation of } \\
\text { equipment }\end{array}$ & 569 & G & $12.7 \%$ & $11.6 \%$ & $17.8 \%$ & $15.6 \%$ & $5.6 \%$ & $19.0 \%$ & $12.0 \%$ & $19.5 \%$ & $24.8 \%$ & $12.5 \%$ \\
\hline Hotels and restaurants & 180 & $\mathrm{H}$ & $15.6 \%$ & $14.4 \%$ & $21.7 \%$ & $18.9 \%$ & $7.2 \%$ & $18.3 \%$ & $11.7 \%$ & $18.9 \%$ & $25.0 \%$ & $15.6 \%$ \\
\hline Financial intermediation & 344 & $\mathrm{~J}$ & $20.9 \%$ & $19.2 \%$ & $26.2 \%$ & $26.9 \%$ & $7.9 \%$ & $28.5 \%$ & $15.1 \%$ & $29.9 \%$ & $34.6 \%$ & $21.5 \%$ \\
\hline Health and social services & 380 & $\mathrm{~N}$ & $29.0 \%$ & $25.3 \%$ & $38.2 \%$ & $28.2 \%$ & $7.9 \%$ & $36.1 \%$ & $14.2 \%$ & $37.1 \%$ & $46.1 \%$ & $29.2 \%$ \\
\hline $\begin{array}{l}\text { Other community and } \\
\text { social and personal } \\
\text { services }\end{array}$ & 296 & $\mathrm{O}$ & $21.3 \%$ & $19.6 \%$ & $26.4 \%$ & $23.5 \%$ & $12.8 \%$ & $22.6 \%$ & $15.5 \%$ & $24.7 \%$ & $32.8 \%$ & $18.2 \%$ \\
\hline \multirow[t]{2}{*}{ Subtotal } & 2619 & & $18.8 \%$ & $20.1 \%$ & $27.2 \%$ & $21.3 \%$ & $7.9 \%$ & $26.2 \%$ & $11.7 \%$ & $27.2 \%$ & $34.4 \%$ & $20.0 \%$ \\
\hline & \multicolumn{12}{|c|}{ National and Foreign Capital } \\
\hline National & 3896 & & $20.8 \%$ & $20.3 \%$ & $27.9 \%$ & $22.1 \%$ & $9.7 \%$ & $26.4 \%$ & $12.7 \%$ & $27.6 \%$ & $34.6 \%$ & $20.9 \%$ \\
\hline Foreign $(* * * *)$ & 436 & & $25.0 \%$ & $25.5 \%$ & $33.7 \%$ & $22.9 \%$ & $16.3 \%$ & $28.4 \%$ & $13.5 \%$ & $29.8 \%$ & $40.4 \%$ & $23.2 \%$ \\
\hline \multirow{4}{*}{\multicolumn{3}{|c|}{$\begin{array}{l}\text { (1) Product or process innovation } \\
\text { (2) New to Market product innovation } \\
\text { (3) Organization or marketing innovation } \\
\text { (4) Technological or non-technological innovation }\end{array}$}} & \multicolumn{10}{|c|}{ (*) In the product definition for all cases we include both new goods and services } \\
\hline & & & \multicolumn{10}{|c|}{$(* *)$ This definition is only available for the 6th innovation survey } \\
\hline & & & \multirow{2}{*}{\multicolumn{10}{|c|}{$\begin{array}{l}(* * *) \text { For the } 5 \text { th survey, this definition refers to innovations that are new to the domestic market or to the world } \\
(* * * *) \text { We consider a company "foreign" if at least } 1 \% \text { of the property belongs to non-residents }\end{array}$}} \\
\hline & & & & & & & & & & & & \\
\hline & & & & & & & Table 2. & & & & & \\
\hline \multirow[t]{2}{*}{ Years 2005-2008 } & & & \multicolumn{5}{|c|}{ Technological Innovation } & \multicolumn{3}{|c|}{ Non-Technological Innovation } & & \\
\hline & $\mathrm{N}$ & CIIU & Product $(*)$ & Process & $\begin{array}{l}\text { Innovative } \\
\text { firms } \\
\text { (1) }\end{array}$ & $\begin{array}{l}\text { In-house } \\
\text { Tech-Innov } \\
\quad(* *)\end{array}$ & $\begin{array}{l}\text { New to } \\
\text { Market }(* * *) \\
\text { (2) }\end{array}$ & Organization & Marketing & $\begin{array}{l}\text { Non-Tech } \\
\text { Innovation (3) }\end{array}$ & $\begin{array}{l}\text { Any Innovation } \\
\text { (4) }\end{array}$ & $\begin{array}{l}\text { Tech and Non- } \\
\text { Tech Innovation } \\
\text { (5) }\end{array}$ \\
\hline \multirow[t]{2}{*}{ All Manuf. Industry } & 2,860 & D & $22.0 \%$ & $26.0 \%$ & $31.5 \%$ & $26.3 \%$ & $13.4 \%$ & $24.9 \%$ & $17.5 \%$ & $28.0 \%$ & $36.8 \%$ & $22.7 \%$ \\
\hline & \multicolumn{12}{|c|}{ National and Foreign Capital } \\
\hline National & 2567 & & $21.1 \%$ & $24.8 \%$ & $30.3 \%$ & $25.2 \%$ & $12.2 \%$ & $24.2 \%$ & $17.0 \%$ & $27.1 \%$ & $35.8 \%$ & $21.6 \%$ \\
\hline Foreign $(* * * *)$ & 293 & & $30.0 \%$ & $36.5 \%$ & $42.3 \%$ & $36.6 \%$ & $23.6 \%$ & $31.4 \%$ & $22.5 \%$ & $36.5 \%$ & $46.1 \%$ & $32.8 \%$ \\
\hline
\end{tabular}


Table 2 shows a comparison between fully domestic firms with those with some foreign participation. In both manufacturing and services, and in technological and nontechnological innovation, firms with foreign capital have a higher propensity to innovate. Interestingly the difference between domestic and foreign firms is much larger in manufacturing than in services.

Innovation inputs can be seen in Tables 3 and 4. Overall, services firms spend more in innovation than manufacturing firms. This is particularly driven by the large expenditure of subsector $\mathrm{K}$, which has more than double the expenditure than manufacturing as a percentage of sales. KIBS as a group also innovates more than manufacturing and more than non-KIBS subsectors. However, unexpectedly, health services, community and social services, and hotels and restaurants have a high level of expenditure in innovation, higher even than manufacturing, a fact that is difficult to explain. When we decompose the expenditure between $R \& D$, machinery and other innovation expenditures, $R \& D$ has a much larger weight in manufacturing than in services (larger then KIBS too), where 21.7 percent of expenditure corresponds to $R \& D$. The most $R \& D$ intensive subsectors in the services industries, are subsector K (which shows a higher importance of R\&D than manufacturing) - 23.7 percent, and financial intermediation (18.6 percent).

Health services and hotels concentrate their innovation expenditure in equipment when compared to the most R\&D intensive sectors, and show lower importance in R\&D as should be expected. The percentage of firms that performed R\&D is again higher in manufacturing (15.5 percent) than in services (8.4 percent) and than in KIBS (11.3 percent), but again also subsector $\mathrm{K}$ has the highest percentage of firms spending in R\&D (16.8 percent). Financial intermediation is the other subsector that has more than 10 percent of firms spending R\&D. When comparing domestic with firms with foreign participation the latter, despite having a larger propensity to produce innovative outputs, they tend to spend less on innovation than their domestic counterparts. Domestic firms in the service sector spend 7.1 percent of sales on average as opposed to 5.3 percent for firms with foreign participation. For the case of manufacturing, the difference is more marked, 6.3 percent vs 2.6 percent. Despite spending less on average foreign owned firms have a higher propensity to spend in R\&D overall, suggesting that the larger expenditure in domestic firms is driven by few heavy spenders. 
Table 3.

\begin{tabular}{|c|c|c|c|c|c|c|c|c|c|c|}
\hline \multirow[t]{2}{*}{ Years 2005-2008 } & & & \multicolumn{6}{|c|}{ Inputs } & \multicolumn{2}{|c|}{ Outputs } \\
\hline & $\mathrm{N}$ & CIIU & $\begin{array}{c}\text { Expenditure } \\
\text { on innovation } \\
\text { (6) }\end{array}$ & $\begin{array}{l}\mathrm{R} \& \mathrm{D} \\
(7)\end{array}$ & $\begin{array}{c}\text { Machinery } \\
\text { Acquisition } \\
\text { (8) }\end{array}$ & $\begin{array}{c}\text { Other } \\
\text { Innovation } \\
\text { activities } \\
\text { (9) }\end{array}$ & $\begin{array}{c}\text { Firms that } \\
\text { performed } \\
\text { R\&D }\end{array}$ & $\begin{array}{c}\text { Firms that } \\
\text { performed } \\
\text { R\&D on a } \\
\text { continuous } \\
\text { basis }\end{array}$ & $\begin{array}{l}\text { Turnover } \\
\text { from product } \\
\text { innovations }\end{array}$ & $\begin{array}{c}\text { Turnover } \\
\text { from new to } \\
\text { market } \\
\text { product } \\
\text { innovations } \\
(*)\end{array}$ \\
\hline \multirow[t]{2}{*}{ All Service Industry } & 4332 & & $6.3 \%$ & $12.6 \%$ & $52.1 \%$ & $35.3 \%$ & $8.4 \%$ & N/A & $6.6 \%$ & $1.6 \%$ \\
\hline & \multicolumn{10}{|c|}{ KIBS } \\
\hline $\begin{array}{l}\text { Real estate, renting } \\
\text { and business activities }\end{array}$ & 843 & K & $13.6 \%$ & $23.7 \%$ & $36.9 \%$ & $39.3 \%$ & $16.8 \%$ & N/A & $11.1 \%$ & $2.6 \%$ \\
\hline $\begin{array}{l}\text { Transport, storage } \\
\text { and communications }\end{array}$ & 870 & I & $4.6 \%$ & $10.5 \%$ & $58.4 \%$ & $31.1 \%$ & $5.9 \%$ & N/A & $4.9 \%$ & $1.3 \%$ \\
\hline \multirow[t]{2}{*}{ Subtotal } & 1713 & & $9.0 \%$ & $17.0 \%$ & $47.9 \%$ & $35.1 \%$ & $11.3 \%$ & N/A & $8.0 \%$ & $1.9 \%$ \\
\hline & \multicolumn{10}{|c|}{ Traditional Services } \\
\hline $\begin{array}{l}\text { Electricity, gas and } \\
\text { water supply }\end{array}$ & 212 & $\mathrm{E}$ & $3.1 \%$ & $8.0 \%$ & $49.0 \%$ & $43.0 \%$ & $7.6 \%$ & N/A & $2.2 \%$ & $1.1 \%$ \\
\hline Construction & 638 & $\mathrm{~F}$ & $3.9 \%$ & $10.2 \%$ & $55.1 \%$ & $34.7 \%$ & $6.9 \%$ & N/A & $6.7 \%$ & $1.6 \%$ \\
\hline $\begin{array}{l}\text { Wholesale and retail } \\
\text { trade and reparation } \\
\text { of equipment }\end{array}$ & 569 & G & $2.6 \%$ & $2.6 \%$ & $67.1 \%$ & $30.2 \%$ & $1.2 \%$ & N/A & $3.1 \%$ & $1.1 \%$ \\
\hline Hotels and restaurants & 180 & $\mathrm{H}$ & $6.5 \%$ & $5.9 \%$ & $67.0 \%$ & $27.1 \%$ & $3.3 \%$ & N/A & $6.5 \%$ & $1.6 \%$ \\
\hline $\begin{array}{l}\text { Financial } \\
\text { intermediation }\end{array}$ & 344 & $\mathrm{~J}$ & $2.6 \%$ & $18.6 \%$ & $34.4 \%$ & $47.0 \%$ & $11.6 \%$ & N/A & $5.0 \%$ & $1.7 \%$ \\
\hline $\begin{array}{l}\text { Health and social } \\
\text { services }\end{array}$ & 380 & $\mathrm{~N}$ & $7.9 \%$ & $9.7 \%$ & $54.1 \%$ & $36.2 \%$ & $8.7 \%$ & N/A & $8.4 \%$ & $0.2 \%$ \\
\hline $\begin{array}{l}\text { Other community and } \\
\text { social and personal } \\
\text { services }\end{array}$ & 296 & $\mathrm{O}$ & $7.3 \%$ & $15.4 \%$ & $53.0 \%$ & $31.6 \%$ & $8.8 \%$ & N/A & $7.4 \%$ & $1.7 \%$ \\
\hline \multirow[t]{2}{*}{ Subtotal } & 2619 & & $4.5 \%$ & $9.7 \%$ & $54.9 \%$ & $35.4 \%$ & $6.6 \%$ & N/A & $5.6 \%$ & $2.1 \%$ \\
\hline & \multicolumn{10}{|c|}{ National and Foreign Capital } \\
\hline National & 3896 & & $7.1 \%$ & $13.0 \%$ & $52.0 \%$ & $35.0 \%$ & $8.3 \%$ & N/A & $6.3 \%$ & $1.5 \%$ \\
\hline Foreign & 436 & & $5.3 \%$ & $16.3 \%$ & $41.3 \%$ & $42.4 \%$ & $9.9 \%$ & N/A & $9.5 \%$ & $2.6 \%$ \\
\hline
\end{tabular}

(6) Total expenditures on innovation (as a \% of total turnover)

(*) This information is only available for the 6 th innovation survey

(7) Expenditure on R\&D as a \% of total expenditure on innovation

(8) Expenditure on machinery acquisition as a $\%$ of total expenditure on innovation

(9) Expenditure on the rest of innovation activities as a \% of total expenditure on innovation

Table 4.

\begin{tabular}{|c|c|c|c|c|c|c|c|c|c|c|}
\hline \multirow[t]{2}{*}{ Years 2005-2008 } & & & \multicolumn{6}{|c|}{ Inputs } & \multicolumn{2}{|c|}{ Outputs } \\
\hline & $\mathrm{N}$ & CIIU & $\begin{array}{c}\text { Expenditure } \\
\text { on innovation } \\
\text { (6) }\end{array}$ & $\begin{array}{c}\text { R\&D } \\
(7)\end{array}$ & $\begin{array}{c}\text { Machinery } \\
\text { Acquisition } \\
\text { (8) }\end{array}$ & $\begin{array}{c}\text { Other } \\
\text { Innovation } \\
\text { activities } \\
\text { (9) }\end{array}$ & $\begin{array}{l}\text { Firms that } \\
\text { performed } \\
\text { R\&D }\end{array}$ & $\begin{array}{l}\text { Firms that } \\
\text { performed } \\
\text { R\&D on a } \\
\text { continuous } \\
\text { basis }\end{array}$ & $\begin{array}{l}\text { Turnover } \\
\text { from product } \\
\text { innovations }\end{array}$ & $\begin{array}{c}\text { Turnover } \\
\text { from new to } \\
\text { market } \\
\text { product } \\
\text { innovations }\end{array}$ \\
\hline \multirow[t]{2}{*}{ All Manuf. Industry } & 2,860 & D & $6.0 \%$ & $21.7 \%$ & $45.4 \%$ & $33.0 \%$ & $15.5 \%$ & N/A & $5.5 \%$ & $1.5 \%$ \\
\hline & \multicolumn{10}{|c|}{ National and Foreign Capital } \\
\hline National & 2567 & & $6.3 \%$ & $20.6 \%$ & $45.7 \%$ & $33.7 \%$ & $14.2 \%$ & N/A & $5.5 \%$ & $1.5 \%$ \\
\hline Foreign & 293 & & $2.6 \%$ & $28.7 \%$ & $43.1 \%$ & $28.2 \%$ & $26.6 \%$ & N/A & $5.3 \%$ & $1.6 \%$ \\
\hline
\end{tabular}


However, despite this issue, firms with foreign capital dedicate a larger proportion of their innovation expenditures to $R \& D$, both in services and manufacturing. Finally, the turnover from innovative products is higher in the services industry than in the manufacturing industry, and again particularly high in subsector $\mathrm{K}$ and the KIBS group in general. Turnover from products new to the markets is generally very low (less than 3 percent of sales) with the same mentioned pattern.

Turning to policy relevant innovation behavior, tables 5 and 6 show first the wellknown fact that manufacturing firms are significantly more export oriented than services firms. Chile is not the exception and the data shows that 31.4 percent of manufacturing firms export, compared to 8.6 percent of services firms. Exporting propensity is heavily biased to foreign capital firms in both sectors: 65 percent of those firms in manufacturing and 19.3 percent in services export, compared to 27.5 percent and 7.4 percent respectively. KIBS industries have a higher propensity to innovate than the rest of services. However, unexpectedly some traditional services subsectors appear as having a relatively high propensity to export. Such is the case of wholesale and retail trade, and hotels and restaurants.

Cooperation, which part of the literature associates with services rather than manufacturing appears also more prevalent services en Chile. Again, KIBS show a marginally higher cooperating pattern than services in general, again foreign firms in both sectors are much more prone to cooperate (particularly with foreign partners, unsurprisingly). Firms that had public support for innovation are also more likely to come from the service sector (6.9 percent of firms as compared to 4.7 percent; KIBS 8.1 percent ). This is surprising since one would think that public support tends to be biased towards more measurable innovation outputs, which happen more clearly in manufacturing. Patent applications are more prevalent in manufacturing, which is to be expected since it is harder to patent in services due to lower appropriability of new ideas. In the services sectors, only subsector $K$ (which includes $R \& D$ activities) has a similar propensity of patent application.

Finally, we added three variables that we include in the regressions and extensions and that we thought are important to analyze descriptively. The first one is firm size (measured as the number of employees), where the average services sector firm in the sample appears to be larger than the manufacturing firm (except for community and social services). Foreign capital firms are significantly larger than domestic firms. Second, we also want to compare 
measures of skills, since the empirical recent literature stresses the fact that one of the main differences between both sectors is a skill bias of the services sector. We included two measures available in the innovation surveys: the proportion of employment that has tertiary education and which is dedicated to $\mathrm{R} \& \mathrm{D}$, and the proportion of total employment that has a professional or technical degree. The latter shows a more complete picture of skills but it is only available for the $6^{\text {th }}$ innovation survey. Regarding the first measure, the data does not seem to confirm the greater skill intensity in services, as both sectors show similar intensity. The exception is subsector $\mathrm{K}$ which has a significantly larger proportion of employment dedicated to R\&D, which also drives the KIBS industry to have a higher figure when compared to manufacturing. Regarding the more general measure of skills we do observe an important difference across the board in favor of services, where this sector has almost double the qualified personnel when compared to manufacturing. The largest skill intensity can be observed again in financial intermediation, business activities and health services. 
Table 5.

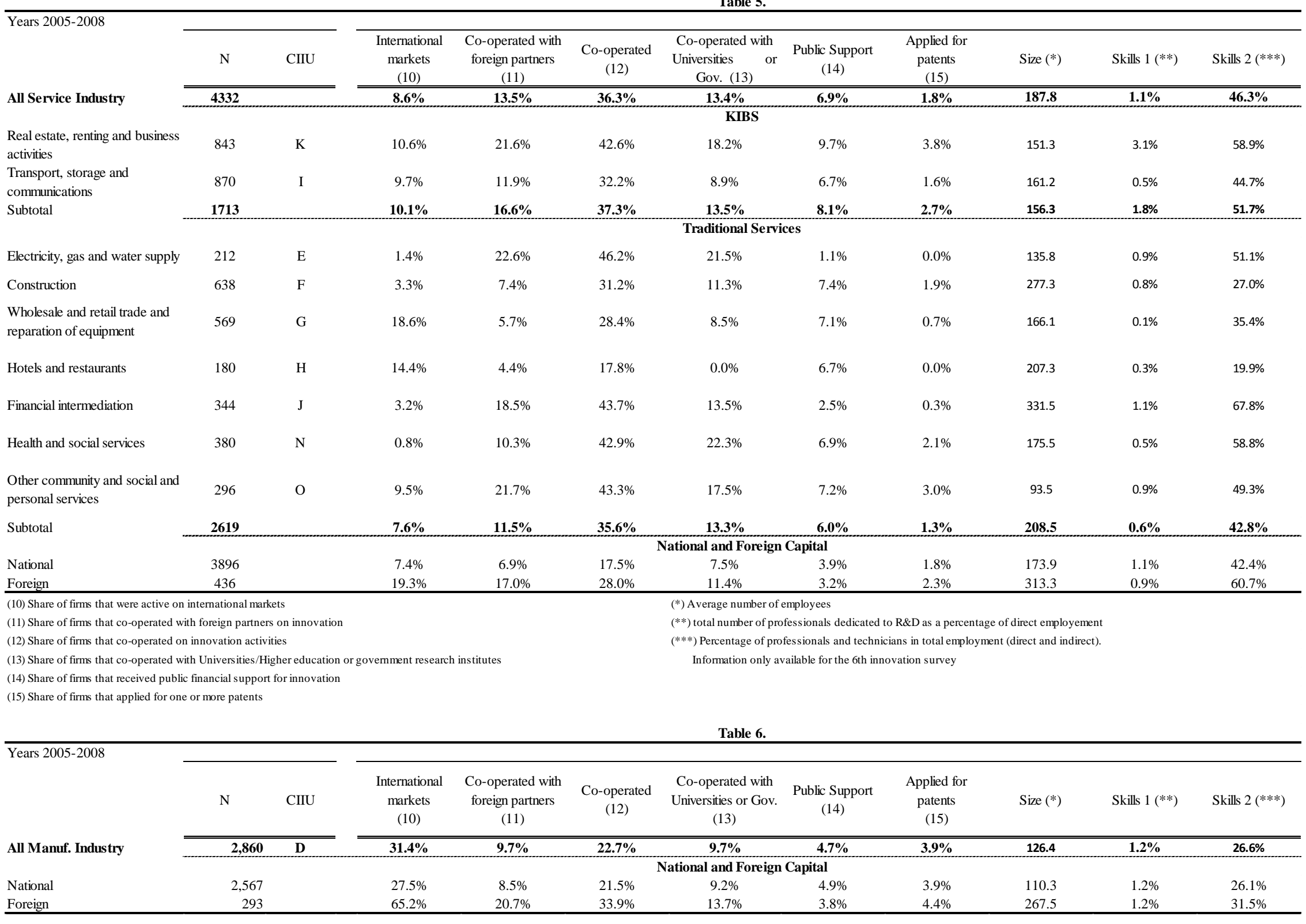


Overall, the descriptive statistics confirm the recent empirical literature, indicating that the services sector is as innovative as manufacturing, albeit with significant heterogeneity within it. The KIBS industry is generally the most innovative within services, although we find some strikingly innovative subsectors. Interestingly, there are no appreciable differences in both technological and non-technological innovation between services and manufacturing.

Something similar can be said about innovation inputs. However, manufacturing is more focused in $R \& D$ than the services industry, except for subsector $K$ within KIBS. Turnover from innovative products seems higher in services than in manufacturing in Chile. As could be expected services seems more inclined to cooperate to innovate than manufacturing, significantly less export oriented than manufacturing, and more skill intensive. In the next section we explain the methodological approach used for our estimations.

\section{Methodology}

Our methodology follows the empirical research line initiated by the influential work of Crépon, et al. (1998) to look at the relationship between innovation investment, innovation outcomes and firm productivity. This approach is based on a multi-equation model that takes into account the whole process of innovation thereby considering the decisions of the firms to engage in innovation activities, the results of these efforts, and their impact on productivity.

Following the CDM approach, our baseline model consists of four equations: (i) the firm's decision to invest in innovation, (ii) the intensity of the investment in innovation, (iii) the knowledge production function linking innovation intensity and innovation outcomes, and (iv) the output production function, in which firm productivity is a function of innovation outcome and other control variables. This basin set up is extended in the following sections to look at the impact other obstacles to innovation, such as financial constraints.

To compare with previous results using this methodology with innovation surveys for manufacturing firms in developing countries, we follow closely the specification employed by Crespi and Zuñiga (2011). First, we estimate a generalized Tobit that considers the decision to invest and the amount invested in innovation. Second, we use the predicted value of innovation intensity (innovation investment per employee) as explanatory variable in the knowledge production function, where the innovation outcome is measured by a categorical variable that 
account for product and process innovation. Finally, the predicted values of innovation outcomes are used as explanatory variables in the output production function ${ }^{11}$.

\subsubsection{Innovation Investment}

We rely on a generalized Tobit framework to model the decision to invest and the amount invested in research activities. Hence, there are two linked equations: (i) the decision to invest in innovation, and (ii) the amount of resources involved, measured as innovation expenditure per employee (in logs). More precisely, we assume that there exists a latent dependent variable $I E_{i}^{*}$ for firm i's innovative effort, given by the following equation:

$I E_{i}^{*}=X_{1 i}^{\prime} \beta+\varepsilon_{i}$

where $X_{1 i}^{\prime}$ is a vector of explanatory variables, $\beta$ is a vector of parameters and $\varepsilon$ an error term. The econometrician observes that $(\log )$ resources are invested in innovation activities, $I E_{i}$, if $I E_{i}^{*}$ is positive or larger than a given threshold.

We assume the following selection equation describing whether a firm is investing in innovation or not:

\section{$I D_{i}=1 \quad$ if $\quad I D_{i}^{*}=W_{i}^{\prime} \alpha+e_{i}>c$, and 0 otherwise. (2)}

Where $I D$ is and observed binary variable equal to zero for firms not investing in innovation and 1 for those investing in innovation, $I D_{i}^{*}$ is the corresponding latent variable such that a firm decided to invest in innovation if it's above a certain threshold denoted by $c$, and $W$ is a vector of explanatory variables.

Conditional on investing, the observed innovation investment $\left(I E_{i}\right)$ is given by:

$I E_{i}=\left(\begin{array}{l}I E_{i}^{*}=Z_{i}^{\prime} \beta+\varepsilon_{i} \quad \text { if } I D_{i}=1 . \\ 0 \quad \text { if } \quad I D_{i}=0 .\end{array}\right)$

The system of equations (2) and (3) is estimated as a generalized Tobit model by maximum likelihood.

\footnotetext{
11 This model may be estimated using alternative econometric techniques as Asymptotic Least Squares, as actually done in the original paper by Crépon, et al. (1998). However, recent works on this issue tend to prefer the less computationally intensive technique of estimating the three components of the model separately using instrumental variables (Griffith at al 2006; Hall et al 2008).
} 
The vector of explanatory variables $\mathrm{W}$ and $\mathrm{Z}$ follows closely those used by Crespi $\mathrm{y}$ Zuñiga (2011). Therefore, we model the firm's decision on whether to invest in innovation considering the following explanatory variables:

- Export: defined as dummy variable for exporters. This variable is used to capture the exposure to international markets that it is expected to increase innovation exports though higher competition and learning effects.

- Firm size: defined as the number of workers (in logs) and it is expected to affect innovation investment positively (Cohen and Levin, 1989).

- Foreign ownership: defined as dummy variable for foreign owned firms. We expect a positive effect in case that foreign owned firm can access to technological information that it is not available for domestic firms. However, previous evidence on the manufacturing firms in Latin America is not conclusive on this positive effect (Crespi and Zuñiga, 2011).

- Patent protection: a dummy equal to one if the firm filed for a patent in the previous period. This variable is included to control for the capacity of the firm to manage intellectual property rights and its past stocks of knowledge. Both should be positively correlated with innovation investment.

The set of explanatory variables for innovation intensity includes the variables defined above and the following additional ones:

- Cooperation: It is captured by a dummy variable that takes the value 1 if the firm has some cooperative arrangement on innovation activities.

- Public finance: defined as a dummy variable that indicates whether the firm uses public resources for funding $R \& D$ investments.

- Sources of information: We consider 3 possible sources and we define these variables as the scores measuring the importance of the following different sources for innovation: (i) market (suppliers, clients, competitors, etc.) (ii) Scientific (universities, public research centers, etc.) and (iii) public (journals, patents, magazines, etc.).

\subsubsection{Knowledge Production Function}

In general, it is assumed that innovative output is related to improvements in firm's productivity. There are, however, several ways to proxy innovation output. The most common proxies used in this literature are the number of patents and share of innovative sales. In this paper, in our basic 
regressions we use one indicator of innovation output. This is defined as dummy variable indicating if the firm declares having introduced either a product or process innovation.

The surveys include several alternatives for product and process innovation. In the case of product innovation, firms are asked for technological improvements of products and introduction of a new product for the firms but not new for the market. For innovation process, the approach is similar. Firms are asked for partial but important improvements and for new technological process for the firm, but not new in the market. Then, we define a product and process innovation if the firm responds affirmatively to any of these alternatives, independently if the product (or process) innovation is new to the firm or to the market.

We estimate a probit model for product and process innovation. This is modeled as follows:

$I_{i}=\delta I E_{i}^{*}+Y_{i}^{\prime} \gamma+\mu_{i}$

Where $I_{i}$ is equal to 1 whether the firm has introduced either a product or process innovation. $I E_{i}^{*}$ is the predicted value of the firm innovative effort (log of innovation investment per worker) form the estimated generalized Tobit equations described above, and $Y_{i}^{\prime}$ is a vector of explanatory variables. This instrumental variable estimation, given by inclusion of the predicted value of $I E_{i}^{*}$ , takes into account the potential endogeneity of investment in innovation. In our basic regressions, following Crespi and Zuñiga (2011), we consider the following explanatory variables: (i) the predicted values of innovation intensity obtained from the Tobit model, (ii) firm size defined as above, (iii) a dummy for exporting firms, and (iv) a dummy for foreign owned firms.

The basic identifying assumption in this methodology is that there are some variables affecting the decision of investing in innovation that do not affect the innovation outcome. There are several variables - included in innovation decisions but not innovation outcomes - for which this assumption is likely to hold. Let us consider, for example, the use of public resources. It can be argued that, in the presence of financial constraints, public resources are useful for financing innovation. However, it is difficult to argue that public financing may increase directly the probability of introducing new products or new technological process. By the same token, the variables that identify the sources of innovation are likely to affect the resources invested in innovation, but not necessarily the innovation outcomes. 


\subsubsection{Output Production Function}

Assuming a Cobb-Douglas production function, the effect of innovation on productivity may be estimated with the following specification:

$$
y_{i}=\alpha_{1} k_{i}+\alpha_{1} I_{i}+v_{i}
$$

Where $\mathrm{y}$ is labor productivity (log of sales per worker), $\mathrm{k}$ is $\log$ of capital per worker, $\mathrm{I}$ is the knowledge input proxied by product and process innovation. One way to deal with the endogeneity of these innovation variables is to introduce in equation (5) the predicted values of the innovation variables from equation (4). As in the previous equation, the identification assumption is that some variables included in knowledge production function, specifically the use of information from several sources, affect the probability of introducing innovations, but not directly the productivity of the firms. As additional covariates for explaining productivity, we include the size of the firms and the share of new equipment over total equipment expenditures ${ }^{12}$. It is important to note that we for estimations of the output production function, we will use lagged values of all the independent variables. In other words, the labor productivity in $t$ will always be regressed against independent variables in $\mathrm{t}-1^{13}$.

\section{Basic Results}

\section{a. Main Estimations}

In this section, we present the results of our specification following the model specification form Crespi and Zuñiga (2011). We begin first by showing and explaining the main variables used in our estimations. These are shown in Table 7 below.

\footnotetext{
${ }^{12}$ Given that we have no information on capital per worker for almost all the period, we use this imperfect measure for controlling by differences in capital across firms. Moreover, this measure is only available for the $5^{\text {th }}$ innovation survey. For this reason we will present also results for both the pooled cross section, without this variable.

${ }^{13}$ The only exception to this will be the estimations made with the ELE survey which ask questions only for one year, unlike the innovation surveys which always ask for two years of information.
} 


\section{Table 7: Variables Used in Estimations}

\begin{tabular}{|c|c|c|}
\hline \multicolumn{2}{|l|}{ Dependent Variables } & Definition \\
\hline Technological Innovation & $\mathrm{TI}$ & Dummy equal to one if the firm introduced product or process innovation \\
\hline \multicolumn{2}{|l|}{ Expenditures on innovation activities per emc IE } & Log of innovation expenditures per employee \\
\hline Productivity & $\mathrm{Y}$ & Log of sales $(\mathrm{Y})$ per employee \\
\hline \multicolumn{3}{|l|}{ Indepentent Variables } \\
\hline Firm Size & EM & Log of the number of employees at the start of the reporting period \\
\hline Export & EX & Dummy equal to one if the firm exports at the start of the reporting period \\
\hline Foreign Ow nership & $\mathrm{FO}$ & Dummy equal to one if foreign capital ow nership is above $0 \%$ at the start of the reporting period \\
\hline Patent Protection & PA & Dummy equal to one if the firm filed for a patent in the previous period \\
\hline Cooperation & $\mathrm{CO}$ & Dummy equal to one if the firm is engaged in collaboration for R\&D \\
\hline Public Finance & $\mathrm{FIN}$ & Dummy equal to one if the firm received public support to finance innovation \\
\hline Importance of market sources of information & INFO1 & Score measuring the importance of suppliers, clients, competitors, consulting firms, and experts. \\
\hline Importance of scientific sources of innovatio & INFO1 & Score measuring the importance of universities, public research center, technological institutions \\
\hline Importance of public sources of information & INFO3 & Score measuring the importance of journals, patents, magazines, expositions, associations, databases, Internet. \\
\hline High Technical Risk constrain & C1 & Dummy equal one if manager perceive that High technical risk is one of the most important innovation constraint. \\
\hline Easy to imitate innovation constraint & $\mathrm{C} 2$ & Dumy equal one if the manager perceive that the innovation is too Easy to imitate and thats is very important constraint. \\
\hline New Equipment & $\mathrm{EQ}$ & $\%$ of new equipment in 3 years over total equipment \\
\hline
\end{tabular}

We first present the results for the innovation investment model for our base specification (manufacturing vs services), which can be seen in Table $8 .{ }^{14}$

\footnotetext{
${ }^{14}$ Table 8 shows the marginal effects of Heckman estimation models for expenditure in innovation. All regressions incorporate sector fixed effects at the 1 digit level, given that only one survey provided two-digit disaggregation, albeit only for manufacturing. Given that we do not have this information for manufacturing industries, we do not perform regression for low and high tech sectors.
} 
Table 8: First Stage Estimation of Probability and Intensity of Innovation Expenditure (marginal effects shown)

\begin{tabular}{|c|c|c|c|c|}
\hline \multirow[b]{2}{*}{ VARIABLES } & \multicolumn{4}{|c|}{ 5th and 6th Innnovation Surveys 2005-2008 } \\
\hline & Manufacturing & Services & Traditional Serv & KIBS \\
\hline \multicolumn{5}{|c|}{ Selection (prob of spending in innov) } \\
\hline Exporting & $\begin{array}{c}0.0786 * * * \\
(0.0232)\end{array}$ & $\begin{array}{c}0.0648^{* *} \\
(0.0286)\end{array}$ & $\begin{array}{c}0.0343 \\
(0.0372)\end{array}$ & $\begin{array}{c}0.0927 * * \\
(0.0435)\end{array}$ \\
\hline Foreign & $\begin{array}{c}0.0232 \\
(0.0309)\end{array}$ & $\begin{array}{c}0.0139 \\
(0.0244)\end{array}$ & $\begin{array}{c}0.0228 \\
(0.0321)\end{array}$ & $\begin{array}{c}-0.00117 \\
(0.0370)\end{array}$ \\
\hline Size & $\begin{array}{c}0.0974 * * * \\
(0.00720)\end{array}$ & $\begin{array}{c}0.0553 * * * \\
(0.00325)\end{array}$ & $\begin{array}{c}0.0567 * * * \\
(0.00431)\end{array}$ & $\begin{array}{c}0.0519 * * * \\
(0.00549)\end{array}$ \\
\hline Patent Protection & $\begin{array}{c}0.359 * * * \\
(0.0526)\end{array}$ & $\begin{array}{c}0.307 * * * \\
(0.0528)\end{array}$ & $\begin{array}{c}0.361 * * * \\
(0.0812)\end{array}$ & $\begin{array}{c}0.209 * * * \\
(0.0790)\end{array}$ \\
\hline \multicolumn{5}{|c|}{ Intensity (log amount spend in innov per employee) } \\
\hline Exporting & $\begin{array}{c}0.645^{* * *} \\
(0.157)\end{array}$ & $\begin{array}{c}0.425^{* *} \\
(0.200)\end{array}$ & $\begin{array}{c}0.136 \\
(0.272)\end{array}$ & $\begin{array}{c}0.581^{* *} \\
(0.294)\end{array}$ \\
\hline Foreign & $\begin{array}{c}0.318 \\
(0.194)\end{array}$ & $\begin{array}{l}0.0983 \\
(0.233)\end{array}$ & $\begin{array}{c}0.429 \\
(0.273)\end{array}$ & $\begin{array}{l}-0.233 \\
(0.378)\end{array}$ \\
\hline Public financial support & $\begin{array}{c}0.276 \\
(0.218)\end{array}$ & $\begin{array}{c}0.472 * * \\
(0.225)\end{array}$ & $\begin{array}{c}0.205 \\
(0.329)\end{array}$ & $\begin{array}{c}0.722^{* *} \\
(0.295)\end{array}$ \\
\hline Patent Protection & $\begin{array}{c}0.258 \\
(0.224)\end{array}$ & $\begin{array}{c}0.662 * * * \\
(0.237)\end{array}$ & $\begin{array}{c}0.416 \\
(0.354)\end{array}$ & $\begin{array}{c}0.412 \\
(0.383)\end{array}$ \\
\hline Co-operation in R\&D & $\begin{array}{c}0.533^{* * *} \\
(0.139)\end{array}$ & $\begin{array}{c}0.677^{* * *} \\
(0.124)\end{array}$ & $\begin{array}{c}0.337^{* *} \\
(0.158)\end{array}$ & $\begin{array}{c}0.996 * * * \\
(0.204)\end{array}$ \\
\hline Market info sources (INFO1) & $\begin{array}{c}-0.0647 \\
(0.174)\end{array}$ & $\begin{array}{c}0.151 \\
(0.172)\end{array}$ & $\begin{array}{l}-0.0763 \\
(0.235)\end{array}$ & $\begin{array}{c}0.171 \\
(0.262)\end{array}$ \\
\hline Scientific sources (INFO2) & $\begin{array}{c}-0.000433 \\
(0.102)\end{array}$ & $\begin{array}{l}-0.120 \\
(0.101)\end{array}$ & $\begin{array}{l}-0.0257 \\
(0.138)\end{array}$ & $\begin{array}{l}-0.226 \\
(0.144)\end{array}$ \\
\hline Other spillovers (INFO3) & $\begin{array}{c}0.00751 \\
(0.148)\end{array}$ & $\begin{array}{l}0.00709 \\
(0.128)\end{array}$ & $\begin{array}{l}-0.182 \\
(0.165)\end{array}$ & $\begin{array}{c}0.177 \\
(0.197)\end{array}$ \\
\hline Observations & 2682 & 4023 & 2,410 & 1,572 \\
\hline
\end{tabular}

Robust standard errors in parentheses

$* * * p<0.01, * * p<0.05, * p<0.1$

Comparing manufacturing and services (specifications 1 and 2), we find that size is important for both sectors as a determinant of the decision to spend in innovation. This is similar to previous findings in Chile and Latin America. However, our results show that it is consistently more important in manufacturing. This coincides with papers such as Iacovone et al (2012) where they find that size is more relevant for manufacturing to engage in innovation and exports. Also, the results show that exporting firms have a higher probability in engaging in innovation investment in both sectors. In contrast, foreign ownership doesn't seem to be correlated with this probability, and patent protection appears to be positively correlated. 
With respect to the intensity equation, again exporting appears to be positively correlated with higher innovation expenditure, with the effect being stronger for manufacturing. Public financial support is positively correlated with larger expenditure particularly for the service sector. The other relevant variable is having sources of cooperation for R\&D. For both manufacturing and services having cooperated to do R\&D allows firms to leverage resources and seems to incentivize larger expenditure in innovation. Finally, all sources of information for innovation appear as non-significant and in some cases with opposite than expected sign. Overall, we do not observe many differences between sectors for the selection and intensity of expenditure in innovation. This may be so because the types of expenditure that are recorded for innovation are clearly intended to measure technological innovation and it is possible that the behavior and determinants in both sectors towards that type of innovation might be similar.

Specifications 3 and 4 separate the analysis of services between KIBS and traditional services. Interestingly, for the selection equation exporting is positively associated with the decision to spend only in KIBS. Size and patent protection are similarly relevant in both subindustries. For the intensity equation, exporting seems again more important for KIBS and not being significant for the decision to innovate in traditional services. Patent protection unexpectedly appears as non-significant for either industry even though when put together the coefficient is significant. Cooperation appears to have 3 times the impact in KIBS than in traditional services. And all sources of information still appear as non-significant.

Second, we show the knowledge production function in Table 9, where we use the predicted $(\log )$ expenditure in innovation per employee estimated in the first stage. The probability of introducing a new product or process is positively and significantly determined by the expenditure in innovation. The predicted innovation expenditure has a bigger impact in the probability of introducing technological innovations in manufacturing revealing a closer relationship between both. Firm size again has a clear positive relation with the introduction of a new product or service, on top of its effect on the size of innovation expenditure. This is also consistent with previous evidence in Crespi and Zuñiga (2011) for manufacturing firms Latin American countries. For all countries considered in that work, larger firms are more likely to innovate even after controlling for the innovation expenditures. And again, as in the predicted value of innovation expenditure, the importance of size is larger (double) for manufacturing in 
the probability of innovating when compared to services.

Table 9: $2^{\text {nd }}$ Stage Estimation: Probability of Innovating in Products, Services or Processes (probit marginal effects shown)

\begin{tabular}{lcc|cc}
\hline & $(1)$ & $(2)$ & $(3)$ & $(4)$ \\
VARIABLES & \multicolumn{2}{c}{ 5th and 6 th } & \multicolumn{2}{c}{ Innnovation Surveys 2005-2008 } \\
\hline Innovation output in product or process & & & & \\
IE_p (predicted Inn exp per employee) & $0.603^{* * *}$ & $0.494^{* * *}$ & $0.166^{* * *}$ & $0.506^{* * *}$ \\
& $(0.0565)$ & $(0.0469)$ & $(0.0350)$ & $(0.0442)$ \\
Size & $0.0753^{* * *}$ & $0.0347^{* * *}$ & $0.0479^{* * *}$ & $0.0325^{* * *}$ \\
& $(0.00812)$ & $(0.00411)$ & $(0.00493)$ & $(0.00666)$ \\
Export (dummy) & $-0.391^{* * *}$ & $-0.247^{* * *}$ & -0.0140 & $-0.301^{* * *}$ \\
& $(0.0348)$ & $(0.0207)$ & $(0.0392)$ & $(0.0209)$ \\
Foreign Ownership (dummy) & $-0.204^{* * *}$ & $-0.0764^{* * *}$ & $-0.0784^{* *}$ & $0.156^{* * *}$ \\
& $(0.0262)$ & $(0.0239)$ & $(0.0334)$ & $(0.0447)$ \\
& & & & \\
Observations & 2,688 & 4,023 & 2,413 & 1,572 \\
\hline
\end{tabular}

Robust standard errors in parentheses

$* * * p<0.01, * * p<0.05, * p<0.1$

An interesting unexpected outcome is the exports dummy coefficient. It is consistently negative and significant. Controlling for the predicted intensity in innovation expenditure and firm size exporting firms have a lower probability of having innovation outputs, and this effect is larger for manufacturing. This is counterintuitive, since exporting firms generally have higher exposure to international competition and thus should have a positive (Schumpeterian) relation with innovation. Finally, firms with foreign ownership have a lower probability of innovating in both sector, but the negative effect is again larger in manufacturing.

When dividing services between KIBS and traditional services, we find that the impact of innovation expenditure on the probability of innovating is much larger in KIBS. On the contrary, size appears to be marginally more relevant for traditional services, and still for both much smaller than for manufacturing. The negative association of exporting with the probability of innovating seems driven by the KIBS industry, which is again hard to explain. Finally, the effect of foreign ownership is very different between the two subindustries. The negative coefficient of specification 2 seems mostly driven by the traditional services. For KIBS the effect is positive and significant. Finally, in table 10 we show the econometric results for the output production function. 
Table 10: Output Production Function

Specification 1: using predicted probability of innovation output

\begin{tabular}{|c|c|c|c|c|c|c|c|c|}
\hline \multirow[b]{4}{*}{ VARIABLES } & \multicolumn{4}{|c|}{ whitout new equipment } & \multicolumn{4}{|c|}{ with new equipment } \\
\hline & (1) & (2) & (3) & (4) & (5) & (6) & (7) & (8) \\
\hline & \multicolumn{4}{|c|}{ 5th and 6th Innnovation Surveys 2005-2008 } & \multicolumn{4}{|c|}{ 5th innovation survey $2005-2006$} \\
\hline & Manufacturing & Services & Traditional Serv & KIBS & Manufacturing & Services & Traditional Serv & KIBS \\
\hline \multicolumn{9}{|c|}{ log labor productivity (sales per worker) } \\
\hline TI_p (Technological innovation) & $\begin{array}{c}1.337 * * * \\
(0.190)\end{array}$ & $\begin{array}{c}0.737^{* * *} \\
(0.148)\end{array}$ & $\begin{array}{c}3.761^{* * *} \\
(0.736)\end{array}$ & $\begin{array}{c}0.750 * * * \\
(0.188)\end{array}$ & $\begin{array}{c}1.114^{* * *} \\
(0.214)\end{array}$ & $\begin{array}{c}0.771^{* * *} \\
(0.211)\end{array}$ & $\begin{array}{c}1.648 * * * \\
(0.598)\end{array}$ & $\begin{array}{c}0.917 * * * \\
(0.240)\end{array}$ \\
\hline Size & $\begin{array}{l}-0.0123 \\
(0.0329)\end{array}$ & $\begin{array}{c}-0.321 * * * \\
(0.0188)\end{array}$ & $\begin{array}{c}-0.456 * * * \\
(0.0451)\end{array}$ & $\begin{array}{c}-0.356^{* * *} \\
(0.0251)\end{array}$ & $\begin{array}{c}0.0432 \\
(0.0448)\end{array}$ & $\begin{array}{c}-0.198 * * * \\
(0.0343)\end{array}$ & $\begin{array}{c}-0.262^{* * *} \\
(0.0454)\end{array}$ & $\begin{array}{c}-0.158 * * * \\
(0.0385)\end{array}$ \\
\hline New Equipment & & & & & $\begin{array}{c}0.00149 \\
(0.00173)\end{array}$ & $\begin{array}{c}0.00164 \\
(0.00182)\end{array}$ & $\begin{array}{l}0.000603 \\
(0.00225)\end{array}$ & $\begin{array}{c}0.00423^{* *} \\
(0.00206)\end{array}$ \\
\hline Constant & $\begin{array}{l}10.14^{* * *} \\
(0.0952)\end{array}$ & $\begin{array}{c}11.00 * * * \\
(0.129)\end{array}$ & $\begin{array}{c}10.86 * * * \\
(0.108)\end{array}$ & $\begin{array}{c}11.56^{* * *} \\
(0.113)\end{array}$ & $\begin{array}{c}9.915^{* * *} \\
(0.139)\end{array}$ & $\begin{array}{c}10.59 * * * \\
(0.167)\end{array}$ & $\begin{array}{c}10.58^{* * *} \\
(0.126)\end{array}$ & $\begin{array}{c}10.30 * * * \\
(0.152)\end{array}$ \\
\hline Observations & 2,688 & 4,023 & 2,413 & 1,572 & 1,415 & 1,359 & 870 & 489 \\
\hline R-squared & 0.041 & 0.197 & 0.239 & 0.142 & 0.050 & 0.149 & 0.188 & 0.065 \\
\hline \multicolumn{9}{|c|}{ Bootstrapped standard errors in parentheses } \\
\hline \multicolumn{9}{|c|}{ Specification 2: using predicted innovation expenditure per employee } \\
\hline & & & & (4) & (5) & (6) & (7) & (8) \\
\hline & \multicolumn{4}{|c|}{ 5th and 6th Innnovation Surveys 2005-2008 } & \multicolumn{4}{|c|}{ 5th innovation survey $2005-2006$} \\
\hline VARIABLES & Manufacturing & Services & Traditional Serv & KIBS & Manufacturing & Services & Traditional Serv & KIBS \\
\hline \multicolumn{9}{|c|}{ log labor productivity (sales per worker) } \\
\hline Size & $\begin{array}{c}-0.0353 \\
(0.0280)\end{array}$ & $\begin{array}{c}-0.305 * * * \\
(0.0149)\end{array}$ & $\begin{array}{c}-0.286^{* * *} \\
(0.0204)\end{array}$ & $\begin{array}{c}-0.342^{* * *} \\
(0.0273)\end{array}$ & $\begin{array}{c}-0.00471 \\
(0.0366)\end{array}$ & $\begin{array}{c}-0.181^{* * *} \\
(0.0263)\end{array}$ & $\begin{array}{c}-0.193^{* * *} \\
(0.0273)\end{array}$ & $\begin{array}{c}-0.139 * * * \\
(0.0410)\end{array}$ \\
\hline IE_p (predicted Inn exp per employee) & $\begin{array}{c}0.736^{* * *} \\
(0.0548)\end{array}$ & $\begin{array}{c}0.384^{* * *} \\
(0.0449)\end{array}$ & $\begin{array}{c}0.734^{* * *} \\
(0.104)\end{array}$ & $\begin{array}{c}0.367^{* * *} \\
(0.0792)\end{array}$ & $\begin{array}{l}0.753 * * * \\
(0.0731)\end{array}$ & $\begin{array}{l}0.431^{* * *} \\
(0.0697)\end{array}$ & $\begin{array}{c}0.542^{* * *} \\
(0.158)\end{array}$ & $\begin{array}{c}0.400 * * * \\
(0.0909)\end{array}$ \\
\hline New Equipment & & & & & $\begin{array}{c}0.00116 \\
(0.00165)\end{array}$ & $\begin{array}{c}0.00173 \\
(0.00171)\end{array}$ & $\begin{array}{l}0.000520 \\
(0.00197)\end{array}$ & $\begin{array}{c}0.00456^{* *} \\
(0.00200)\end{array}$ \\
\hline Constant & $\begin{array}{c}7.367^{* * *} \\
(0.194)\end{array}$ & $\begin{array}{c}10.26 * * * \\
(0.140)\end{array}$ & $\begin{array}{c}9.181^{* * *} \\
(0.256)\end{array}$ & $\begin{array}{c}10.32^{* * *} \\
(0.320)\end{array}$ & $\begin{array}{c}6.950 * * * \\
(0.265)\end{array}$ & $\begin{array}{c}9.058^{* * *} \\
(0.283)\end{array}$ & $\begin{array}{c}9.402^{* * *} \\
(0.413)\end{array}$ & $\begin{array}{c}8.965 * * * \\
(0.389)\end{array}$ \\
\hline Observations & 2,688 & 4,023 & 2,413 & 1,572 & 1,415 & 1,359 & 870 & 489 \\
\hline R-squared & 0.099 & 0.204 & 0.246 & 0.148 & 0.104 & 0.157 & 0.197 & 0.075 \\
\hline
\end{tabular}

Bootstrapped standard errors in parentheses

$* * * \mathrm{p}<0.01, * * \mathrm{p}<0.05, * \mathrm{p}<0.1$

To deal with endogeneity problems we use the predicted values of innovation outputs (specification 1) and innovation inputs (specification 2) as knowledge inputs. In the first two regressions we show a comparison between manufacturing and services. In the second two we compare traditional services with KIBS. We added four additional regressions because the variable for new equipment is only available for the $5^{\text {th }}$ survey. For that reason we provide results using that variable (regressions 5 to 8) and not using it while using both surveys pooled (regressions 1 to 4 ). As in the previous equation, the identification assumption is that some variables included in knowledge production function, specifically lower appropriability and the interaction with suppliers and customers, affect the probability of introducing innovations, but 
not directly the productivity of the firms. Also, as in Crespi and Zúñiga (2011), since we use estimated independent variables rather than the actual ones, we need to correct for the standard errors in the equations for innovation output and the knowledge production function; this is done by bootstrapping.

The estimations show that in both manufacturing and services the knowledge inputs have a significant positive impact in labor productivity. This is generally the case for both specification 1 (using the predicted probability of producing innovation), and specification 2 (using the predicted expenditure in innovation). In both specifications 1 and 2 the impact of the knowledge input in labor productivity seems larger for manufacturing than for services. Interestingly, as in the case for exports for the knowledge production function, now when controlling for predicted knowledge inputs, size has a negative effect in labor productivity once its effect through innovation expenditure or innovation output is taken into account. The results are very similar if we use only the $5^{\text {th }}$ innovation survey (regressions 5-6) and we include the investment in new equipment. However this could be a reflection that the variable is not a good proxy for capital stock and in fact it is not significant in regressions 5 and 6 in both specifications.

The predicted probability of introducing innovative products or processes is significant for both KIBS and traditional services, although it appears to be particularly relevant for the traditional services industries. The same appears to be true for Innovation expenditure.

Overall, the CDM model a la Crespi and Zuñiga appears to be valid for both manufacturing and services. The coefficients in general have similar signs and level of significance. The differences one can observe are mostly of coefficient sizes. Notwithstanding, one can observe differences between KIBS and traditional services, where variables are generally more important in KIBS in the first and second stages, but not so in the productivity equation.

\section{Extensions}

As an extension to the benchmark estimations of Crespi and Zuniga (2011) we provide estimations analyzing the differential impact of different obstacles to innovation, and we then assess the importance of skills and non-technological innovation, which according to the empirical literature have been identified as particularly relevant for the services sector. 


\section{a) Obstacles to Innovation}

We first provide similar estimations to the basic specification, but including measures of obstacles to innovation. We are particularly interested in the effect of financial restrictions on innovation expenditures. However, it is well known self-reported financial constraint has serious selection problems. To correct this problem, we follow the methodology applied by Savignac (2008) and Alvarez and Crespi (2011), and we use a predicted value of this variable to control for selection ${ }^{15}$. Since only ELE has questions on financial restrictions and information on balance sheet variables, we can only provide results for that survey which include this type of restriction. One of the questions in this Survey allows defining a direct measure of credit constraints for innovation. Firms are asked to identify the main two factors (from a specific list of eight closed and one open alternative) that are perceived as obstacle or disincentive to innovation. Similarly to Alvarez and Crespi (2011), we define a firm to be credit constrained if the alternative: "difficulty for obtaining adequate financing" is declared to be one of these two main obstacles.

An initial stage for estimating a predicted value for financial restrictions is shown in Table 11. ${ }^{16}$ The variables included as determinants of credit constraints are financial variables (existence of collateral, debt to sales ratio, and distributed dividends), technological competitiveness (if the firm uses internet in different processes), human capital (of CEO and workers), and a set of dummy variables for firm size. The regression shows that the larger the firm the lower the probability of being financially constrained (omitted category are the smallest firms), the higher the human capital and age of the firm and CEO the lower the probability of being constrained, and having debt lowers the chance of declaring that you are constrained financially. Also unexpectedly, having collateral with fixed assets is associated (at the 10 percent level) with a higher probability of being financially constrained. Also using internet in different ways is also associated with this constrain.

\footnotetext{
${ }^{15}$ We use the more restricted estimation in their paper, not considering firms that did not innovate and did not feel restricted by financial issues.

${ }^{16}$ The ELE database contains close to 6200 observations. However, several variables used in the regressions have missing values. For this reason they are dropped from the estimation.
} 
Table 11: Probit Regression of the Probability of Being Financially Constrained (marginal effects shown)

\begin{tabular}{|c|c|}
\hline & (1) \\
\hline \multicolumn{2}{|c|}{ Dependent Variable: Is your firm financially constrained? } \\
\hline Colateral with fixed assets (dummy) & $\begin{array}{l}0.0495^{\star} \\
(0.0279)\end{array}$ \\
\hline ratio of debt to sales & $\begin{array}{c}-0.00262^{* * *} \\
(0.000922)\end{array}$ \\
\hline$\%$ of dividends distributed & $\begin{array}{l}-0.0530 \\
(0.0412)\end{array}$ \\
\hline Firm age & $\begin{array}{l}-0.00159^{* *} \\
(0.000640)\end{array}$ \\
\hline CEO age & $\begin{array}{c}-0.00228^{* * *} \\
(0.000639)\end{array}$ \\
\hline CEO has tertiary education (dummy) & $\begin{array}{c}-0.0366^{\star \star} \\
(0.0162)\end{array}$ \\
\hline$\%$ of workers with tertiary education & $\begin{array}{c}-0.0758^{\star \star *} \\
(0.0208)\end{array}$ \\
\hline Firm has internet & $\begin{array}{c}0.0182 \\
(0.0179)\end{array}$ \\
\hline Firm has a web page & $\begin{array}{c}0.0784^{* * *} \\
(0.0185)\end{array}$ \\
\hline Firms sells through internet & $\begin{array}{l}0.111^{\star \star} \\
(0.0510)\end{array}$ \\
\hline Firm buys through internet & $\begin{array}{l}0.0641^{* *} \\
(0.0264)\end{array}$ \\
\hline Dummy Size 2 & $\begin{array}{c}-0.105^{\star \star *} \\
(0.0165)\end{array}$ \\
\hline Dummy Size 3 & $\begin{array}{l}-0.155^{\star * *} \\
(0.0227)\end{array}$ \\
\hline Dummy Size 4 & $\begin{array}{c}-0.257^{\star \star \star} \\
(0.0181)\end{array}$ \\
\hline Observations & 4,906 \\
\hline
\end{tabular}

Table 12 below shows the first stage of the Crespi and Zuniga (2011) with constraints to innovation for the ELE (specifications 1 and 2 provide the estimations with no restrictions as a comparison). Specifications 3 and 4 show that most constraints appear as not significant determinants of the amount spent in innovation (the coefficients in the services sector are actually opposite to what one could expect). Specifications 5 and 6 include our predicted probability of financial restrictions. Financial restrictions appear to be particularly important 
for services, and easiness of has the expected sign for services (but still not significant) Surprisingly the financial constraint variable is not significant for manufacturing, albeit with the expected sign. This could be due to a low $\mathrm{N}$ for manufacturing firms. Finally, columns 7 and 8 exclude the firms that did not innovate and declared not having any restrictions to innovate. In Alvarez and Crespi this exclusion implied a significant change of sign and magnitude of the coefficient of financial constraints. Unexpectedly, the coefficients here are almost exactly the same as columns 5 and 6. These dropped firms don't seem to have generated a bias in this case, but this is clearly counterintuitive.

Table 12: First Stage with ELE and Financial Constraints

\begin{tabular}{|c|c|c|c|c|c|c|c|c|}
\hline \multirow{4}{*}{ VARIABLES } & (1) & (2) & (3) & (4) & (5) & (6) & (7) & (8) \\
\hline & \multicolumn{8}{|c|}{ Encuesta Longitudinal } \\
\hline & \multirow[t]{2}{*}{ Manuf } & \multirow[t]{2}{*}{ Services } & \multirow[t]{2}{*}{ Manuf } & Services & Manuf (FC) & Services (FC) & Manuf & Services \\
\hline & & & & & \multicolumn{2}{|c|}{ Adding Financial Constr } & \multicolumn{2}{|c|}{ Droping those not constr } \\
\hline \multicolumn{9}{|l|}{ Selection (prob of spendir } \\
\hline Exporting & $\begin{array}{l}0.0905^{*} \\
(0.0538)\end{array}$ & $\begin{array}{c}0.165^{* * *} \\
(0.0299)\end{array}$ & $\begin{array}{l}0.0906^{*} \\
(0.0538)\end{array}$ & $\begin{array}{c}0.165^{* * *} \\
(0.0299)\end{array}$ & $\begin{array}{c}0.104^{*} \\
(0.0617)\end{array}$ & $\begin{array}{l}0.123^{* * *} \\
(0.0341)\end{array}$ & $\begin{array}{l}0.138^{* *} \\
(0.0668)\end{array}$ & $\begin{array}{c}0.110^{* * *} \\
(0.0381)\end{array}$ \\
\hline Foreign & $\begin{array}{c}0.205^{* * *} \\
(0.0783)\end{array}$ & $\begin{array}{l}0.0573 * \\
(0.0328)\end{array}$ & $\begin{array}{c}0.205^{* * *} \\
(0.0783)\end{array}$ & $\begin{array}{l}0.0573 * \\
(0.0328)\end{array}$ & $\begin{array}{c}0.255^{* * *} \\
(0.0899)\end{array}$ & $\begin{array}{c}0.0123 \\
(0.0343)\end{array}$ & $\begin{array}{c}0.356 * * * \\
(0.0877)\end{array}$ & $\begin{array}{l}0.00485 \\
(0.0408)\end{array}$ \\
\hline Size & $\begin{array}{c}0.119 * * * \\
(0.0124)\end{array}$ & $\begin{array}{l}0.113^{* * *} \\
(0.00451)\end{array}$ & $\begin{array}{c}0.119 * * * \\
(0.0124)\end{array}$ & $\begin{array}{l}0.113^{* * *} \\
(0.00451)\end{array}$ & $\begin{array}{c}0.0855^{* * *} \\
(0.0129)\end{array}$ & $\begin{array}{l}0.0858^{* * *} \\
(0.00412)\end{array}$ & $\begin{array}{c}0.0830 * * * \\
(0.0141)\end{array}$ & $\begin{array}{c}0.0861^{* * *} \\
(0.00499)\end{array}$ \\
\hline \multicolumn{9}{|c|}{ Intensity (log amount spend in innov per employee) } \\
\hline Exporting & $\begin{array}{l}0.386^{*} \\
(0.218)\end{array}$ & $\begin{array}{c}0.207 \\
(0.140)\end{array}$ & $\begin{array}{l}0.404^{*} \\
(0.218)\end{array}$ & $\begin{array}{c}0.207 \\
(0.140)\end{array}$ & $\begin{array}{l}0.597^{* *} \\
(0.302)\end{array}$ & $\begin{array}{l}0.0517 \\
(0.192)\end{array}$ & $\begin{array}{l}0.528^{*} \\
(0.308)\end{array}$ & $\begin{array}{l}0.216 \\
(0.204)\end{array}$ \\
\hline Foreign & $\begin{array}{c}0.299 \\
(0.317)\end{array}$ & $\begin{array}{c}0.717^{* * *} \\
(0.163)\end{array}$ & $\begin{array}{c}0.283 \\
(0.317)\end{array}$ & $\begin{array}{c}0.717^{* * *} \\
(0.163)\end{array}$ & $\begin{array}{c}0.174 \\
(0.425)\end{array}$ & $\begin{array}{c}0.433 * \\
(0.223)\end{array}$ & $\begin{array}{c}0.270 \\
(0.421)\end{array}$ & $\begin{array}{c}0.585^{* *} \\
(0.236)\end{array}$ \\
\hline Public financial support & $\begin{array}{l}-0.482 \\
(0.789)\end{array}$ & $\begin{array}{c}0.897^{* * *} \\
(0.303)\end{array}$ & $\begin{array}{l}-0.471 \\
(0.753)\end{array}$ & $\begin{array}{c}0.897^{* * *} \\
(0.303)\end{array}$ & $\begin{array}{c}-2.067^{* *} \\
(1.000)\end{array}$ & $\begin{array}{l}0.824^{* *} \\
(0.356)\end{array}$ & $\begin{array}{c}-2.071^{* *} \\
(1.017)\end{array}$ & $\begin{array}{c}0.968^{* *} \\
(0.435)\end{array}$ \\
\hline High technical risk & & & $\begin{array}{l}-0.226 \\
(0.200)\end{array}$ & $\begin{array}{l}0.0129 \\
(0.124)\end{array}$ & $\begin{array}{c}-0.214 \\
(0.246)\end{array}$ & $\begin{array}{r}0.0347 \\
(0.144)\end{array}$ & $\begin{array}{l}-0.233 \\
(0.251)\end{array}$ & $\begin{array}{l}0.0270 \\
(0.146)\end{array}$ \\
\hline Easiness of imitation & & & $\begin{array}{l}-0.225 \\
(0.663)\end{array}$ & $\begin{array}{l}0.0229 \\
(0.350)\end{array}$ & $\begin{array}{c}-0.145 \\
(0.831)\end{array}$ & $\begin{array}{c}-0.109 \\
(0.433)\end{array}$ & $\begin{array}{l}-0.175 \\
(0.838)\end{array}$ & $\begin{array}{c}-0.0865 \\
(0.430)\end{array}$ \\
\hline Financial Constraint & & & & & $\begin{array}{l}-1.221 \\
(1.254)\end{array}$ & $\begin{array}{c}-3.550 * * * \\
(0.550)\end{array}$ & $\begin{array}{r}-1.230 \\
(1.334)\end{array}$ & $\begin{array}{c}-3.344 * * * \\
(0.624)\end{array}$ \\
\hline \multicolumn{9}{|l|}{ Patent Protection } \\
\hline \multicolumn{9}{|l|}{ Co-operation in R\&D } \\
\hline Observations & 899 & 5,393 & 899 & 5,393 & 760 & 4,665 & 628 & 3,293 \\
\hline
\end{tabular}


Tables 13 and 14 show the $2^{\text {nd }}$ and $3^{\text {rd }}$ stage, when we include constraints to innovation.

Table 13: Probability of Innovating (probit marginal effects shown)

\begin{tabular}{|c|c|c|c|c|c|c|c|c|}
\hline \multirow{4}{*}{ VARIABLES } & \multirow[t]{2}{*}{ (1) } & \multirow[t]{2}{*}{ (2) } & \multirow{2}{*}{\multicolumn{6}{|c|}{$\begin{array}{l}\text { (5) } \\
\text { Encuesta Longitudinal }\end{array}$}} \\
\hline & & & & & & & & \\
\hline & \multirow[t]{2}{*}{ Manuf } & \multirow[t]{2}{*}{ Services } & Manuf & Services & Manuf (FC) & Services (FC) & Manuf & Services \\
\hline & & & \multicolumn{2}{|c|}{$\mathrm{w} /$ other constraints } & \multicolumn{2}{|c|}{ Adding Financial Constr } & \multicolumn{2}{|c|}{ Droping those not constr } \\
\hline \multicolumn{9}{|l|}{ Innovation output in product or process } \\
\hline \multirow[t]{2}{*}{ IE_p (predicted Inn exp per employee) } & $-0.845^{*}$ & 0.152 & -0.0932 & 0.151 & -0.135 & $-0.0411^{*}$ & 0.0568 & 0.0192 \\
\hline & $(0.457)$ & $(0.0970)$ & $(0.170)$ & $(0.0966)$ & $(0.0888)$ & $(0.0225)$ & $(0.0855)$ & $(0.0318)$ \\
\hline \multirow[t]{2}{*}{ Size } & $0.0770 * * *$ & $0.0737^{* * *}$ & $0.0786 * * *$ & $0.0737 * * *$ & $0.0881^{* * *}$ & $0.0756 * * *$ & $0.0799 * * *$ & $0.0817^{* * *}$ \\
\hline & $(0.0113)$ & $(0.00352)$ & $(0.0113)$ & $(0.00352)$ & $(0.0138)$ & $(0.00484)$ & $(0.0148)$ & $(0.00665)$ \\
\hline \multirow[t]{2}{*}{ Export (dummy) } & $0.362^{* *}$ & -0.0403 & 0.0751 & -0.0395 & $0.173^{*}$ & 0.0572 & 0.0694 & 0.00442 \\
\hline & $(0.165)$ & $(0.0595)$ & $(0.0859)$ & $(0.0593)$ & $(0.0915)$ & $(0.0365)$ & $(0.0920)$ & $(0.0450)$ \\
\hline \multirow[t]{2}{*}{ Foreign Ownership (dummy) } & $0.392^{* * *}$ & -0.0556 & 0.153 & -0.0546 & $0.236^{* *}$ & $0.149 * * *$ & $0.234^{* *}$ & $0.169 * * *$ \\
\hline & $(0.127)$ & $(0.0788)$ & $(0.0951)$ & $(0.0787)$ & $(0.0987)$ & $(0.0442)$ & $(0.115)$ & $(0.0568)$ \\
\hline Observations & 899 & 5,393 & 899 & 5,393 & 681 & 4,225 & 564 & 2,988 \\
\hline
\end{tabular}

Robust standard errors in parentheses

$* * * p<0.01, * * p<0.05, * p<0.1$

Against what we observed in the innovation surveys, when using ELE (with or without financial constraints) the predicted value of innovation expenditures appears not significant or with the opposite than expected sign. Table 14 shows the results of the output production function. However this results should be analyzed with care since the dependent variable is concurrent with the independent variables (we do not have time variation to use lagged independent variables). Moreover we do not have data on capital or new equipment acquisition. Finally, the first stage entered without being significant or with the wrong sign into the second stage, which generated a predicted value of the probability of innovating. With that in mind, Table 14 shows that firms innovating have a very significant effect in labor productivity (except strangely for the services sector and only for the case of inclusion of financial restrictions, but without excluding firms that did not innovate and did not have constraints). Except in one specification for services, size, once controlling for the probability of innovation is negatively correlated with concurrent labor productivity. This is coherent with what we found in the base case model for the $5^{\text {th }}$ and $6^{\text {th }}$ innovation surveys.

When we use the predicted value of innovation expenditure instead of the predicted value of innovative output as an independent variable influencing labor productivity (specification 2), we find that the predicted expenditure is positively and significantly associated with labor productivity. When excluding financial constraints the coefficients are 
larger for manufacturing. However, once we include the financial restrictions (in the first stage), the coefficient becomes larger for the services sector.

Table 14: $3^{\text {rd }}$ Stage (output production function)

Specification 1: using predicted probability of innovation output

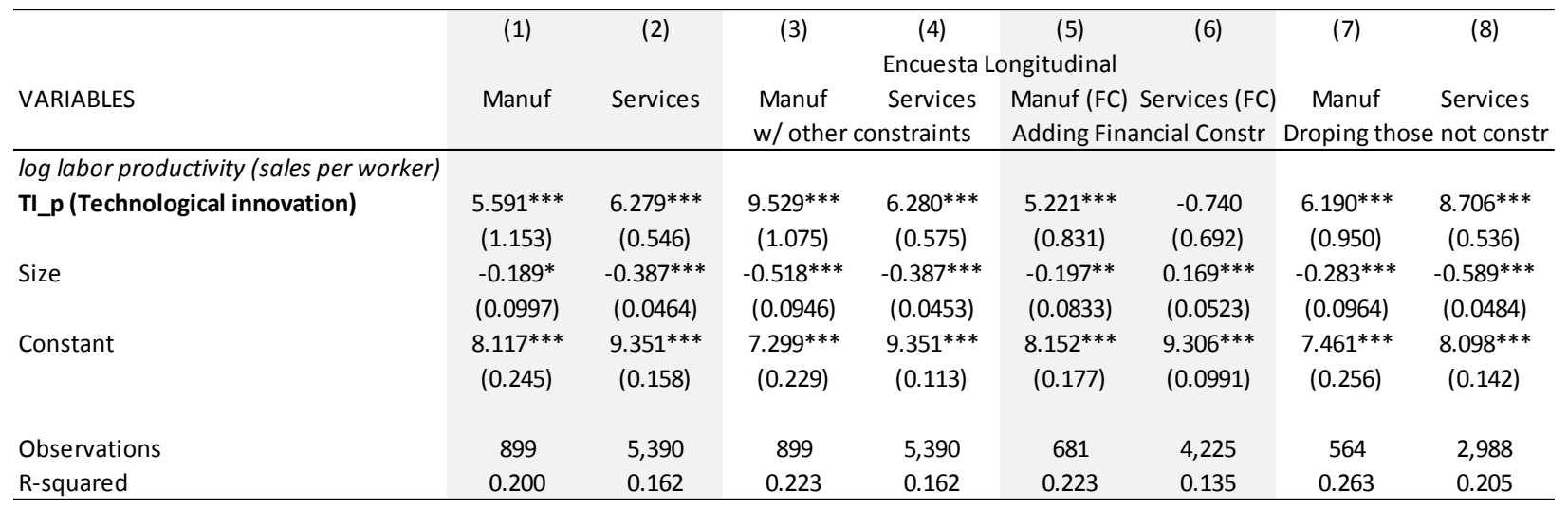

Standard errors in parentheses

*** $p<0.01, * * p<0.05, * p<0.1$

Specification 2: using predicted innovation expenditure per employee

\begin{tabular}{|c|c|c|c|c|c|c|c|c|}
\hline \multirow{4}{*}{ VARIABLES } & (1) & (2) & (3) & (4) & (5) & (6) & (7) & (8) \\
\hline & \multicolumn{8}{|c|}{ Encuesta Longitudinal } \\
\hline & Manuf & Services & Manuf & Services & Manuf (FC) & Services (FC) & Manuf & Services \\
\hline & & & \multicolumn{2}{|c|}{$\mathrm{w} /$ other constraints } & Adding Fin & ancial Constr & \multicolumn{2}{|c|}{ Droping those not const } \\
\hline \multicolumn{9}{|l|}{ log labor productivity (sales per worker) } \\
\hline Size & $\begin{array}{c}0.174^{* * *} \\
(0.0243)\end{array}$ & $\begin{array}{c}0.0579 * * * \\
(0.0101)\end{array}$ & $\begin{array}{c}0.193 * * * \\
(0.0245)\end{array}$ & $\begin{array}{c}0.0580^{* * *} \\
(0.0101)\end{array}$ & $\begin{array}{c}0.141^{* * *} \\
(0.0432)\end{array}$ & $\begin{array}{c}-0.175^{* * *} \\
(0.0171)\end{array}$ & $\begin{array}{c}0.160^{* * *} \\
(0.0438)\end{array}$ & $\begin{array}{c}-0.123^{* * *} \\
(0.0204)\end{array}$ \\
\hline IE_p (predicted Inn exp per employee) & $\begin{array}{c}1.751^{* * *} \\
(0.198)\end{array}$ & $\begin{array}{l}1.041^{* * *} \\
(0.0791)\end{array}$ & $\begin{array}{c}1.469 * * * \\
(0.204)\end{array}$ & $\begin{array}{l}1.039^{* * *} \\
(0.0782)\end{array}$ & $\begin{array}{c}1.155^{* * *} \\
(0.258)\end{array}$ & $\begin{array}{l}1.965 * * * \\
(0.0812)\end{array}$ & $\begin{array}{c}0.963^{* * *} \\
(0.201)\end{array}$ & $\begin{array}{l}1.792^{* * *} \\
(0.0761)\end{array}$ \\
\hline New Equipment & & & & & $\begin{array}{c}1.16 \mathrm{e}-05 \\
(0.00207)\end{array}$ & $\begin{array}{c}0.00238 \\
(0.00212)\end{array}$ & $\begin{array}{l}0.000899 \\
(0.00165)\end{array}$ & $\begin{array}{l}0.000651 \\
(0.00140)\end{array}$ \\
\hline Constant & $\begin{array}{l}-2.532^{*} \\
(1.330)\end{array}$ & $\begin{array}{c}4.235^{* * *} \\
(0.368)\end{array}$ & $\begin{array}{l}-0.648 \\
(1.373)\end{array}$ & $\begin{array}{c}2.440^{* * *} \\
(0.562)\end{array}$ & $\begin{array}{c}1.784 \\
(1.637)\end{array}$ & $\begin{array}{c}1.731^{* * *} \\
(0.306)\end{array}$ & $\begin{array}{l}3.079^{* *} \\
(1.251)\end{array}$ & $\begin{array}{c}1.905^{* * *} \\
(0.290)\end{array}$ \\
\hline Observations & 899 & 5,390 & 899 & 5,390 & 681 & 4,225 & 564 & 2,988 \\
\hline R-squared & 0.229 & 0.180 & 0.219 & 0.180 & 0.268 & 0.370 & 0.266 & 0.365 \\
\hline
\end{tabular}

Standard errors in parentheses

*** $p<0.01, * * p<0.05, * p<0.1$

Summarizing, when including financial restrictions using the logic of Alvarez and Crespi, we find that they are associated with a decrease in the expenditure in innovation, particularly so in the services sector. However, not mattering if we include them or not, the expenditure in innovation in ELE does not appear to be related to the probability of innovating. This could reflect a different way of measuring expenditure (which included a broader category of capital expenditures than what we observe in innovation surveys). 


\section{b) Skill Intensity}

As an additional extension we want to test whether some firm characteristics and output measures found to be relevant to services firms in the literature play a (differential) role in the case of Chile. One of them is skills, which seem to be more important for innovating and exporting (Iacovone et al (2012), Pires et al. (2008) and Eickelpasch and Vogel (2009)) in the service sector than in manufacturing.

We replicate first the original econometric specification but adding a measure of skill intensity in the innovation investment regression. We test two definitions of skill intensity. First, the percentage of the firm employees that have a $\mathrm{PhD}$, Masters or engineer degree plus the technical personnel, all of which work on R\&D. This measure is available for both surveys. We analyze this measure incorporating it in the first stage (selection equation) and third stage, and in all stages in a second specification. Second, we use the percentage of employees that have professional or technical education. This measure is actually more appropriate to measure skills. However it is only available for the $6^{\text {th }}$ innovation survey. We acknowledge that these variables are likely to be endogenous. For this reason we will also provide an estimation using instrumental variables, which we explain below.

Table 15 shows the Heckman estimation incorporating skills in the selection equation. Its coefficient is significant and positive for both manufacturing and services. However, it has a larger impact in manufacturing. This coincides with a decrease in the importance (coefficient size and significance) of the export status for manufacturing, which becomes not significant. After incorporating skills, the variables of public financial support and exporting status become non-significant for services in the intensity equation. Cooperation remains a robust variable for both manufacturing and services in influencing the extent of innovation expenditure. When dividing the services sector in KIBS and traditional industries, patent protection loses importance in the KIBS sector when controlling for skills in the selection equation. Also the importance of size decreases relative to traditional services industries. For the intensity equation the changes in the services sector as a whole seem driven by changes mostly coming from the KIBS subsector, since the changes in significance of the variables explained coincide. 
Table 15: Innovation Selection and Expenditure and Role of Skills

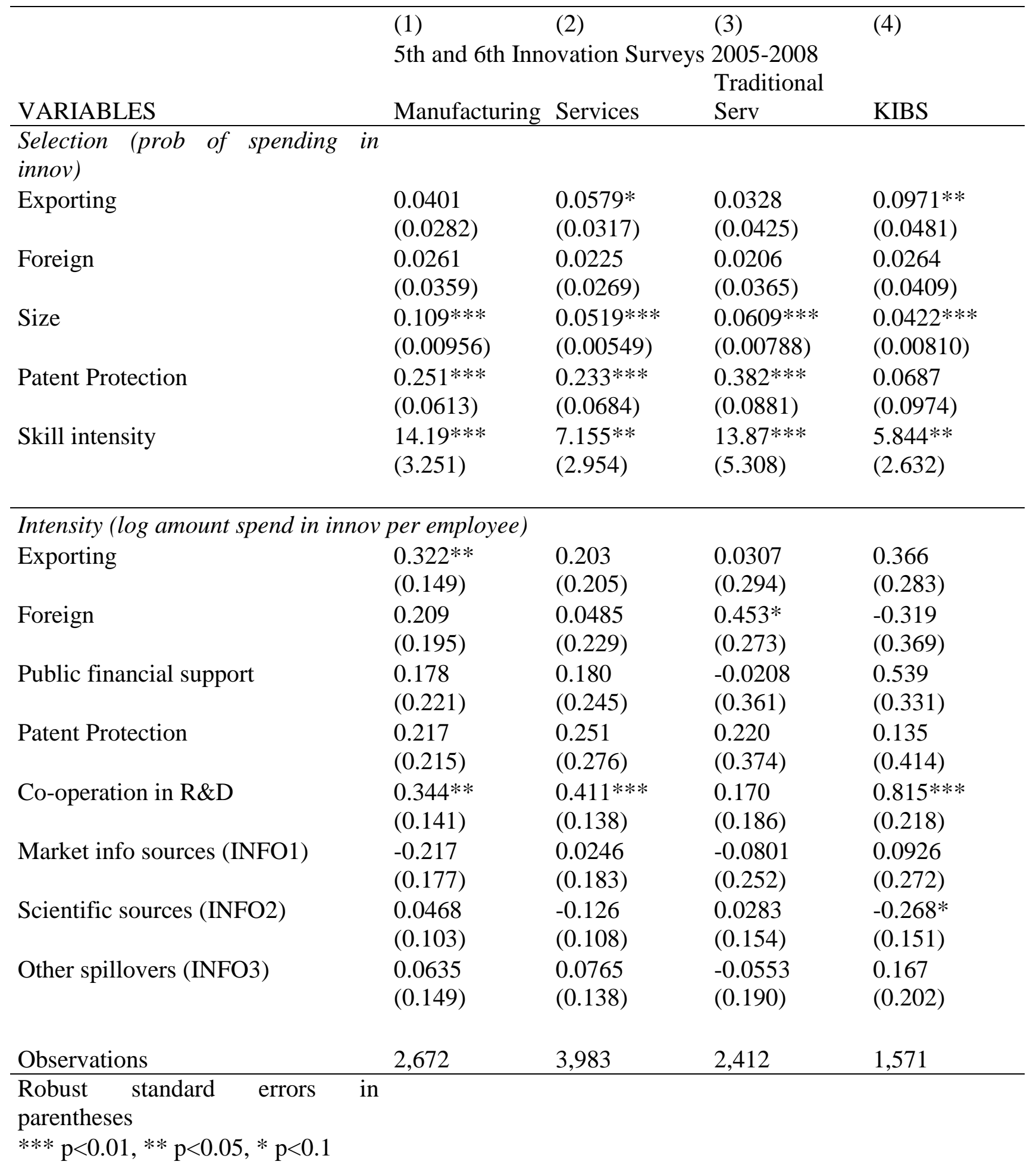


Next we look at the knowledge production function, which can be seen in Table 16. The only difference with the base model is that the importance of the predicted expenditure in innovation (which now includes skills as an explanatory variable) increases, augmenting the coefficients for manufacturing and services from 0.6 and 0.5 to 1.15 and 1.16 respectively. We do not observe noticeable variation in the estimations of KIBS/traditional industries

Table 16: Knowledge Productions Function

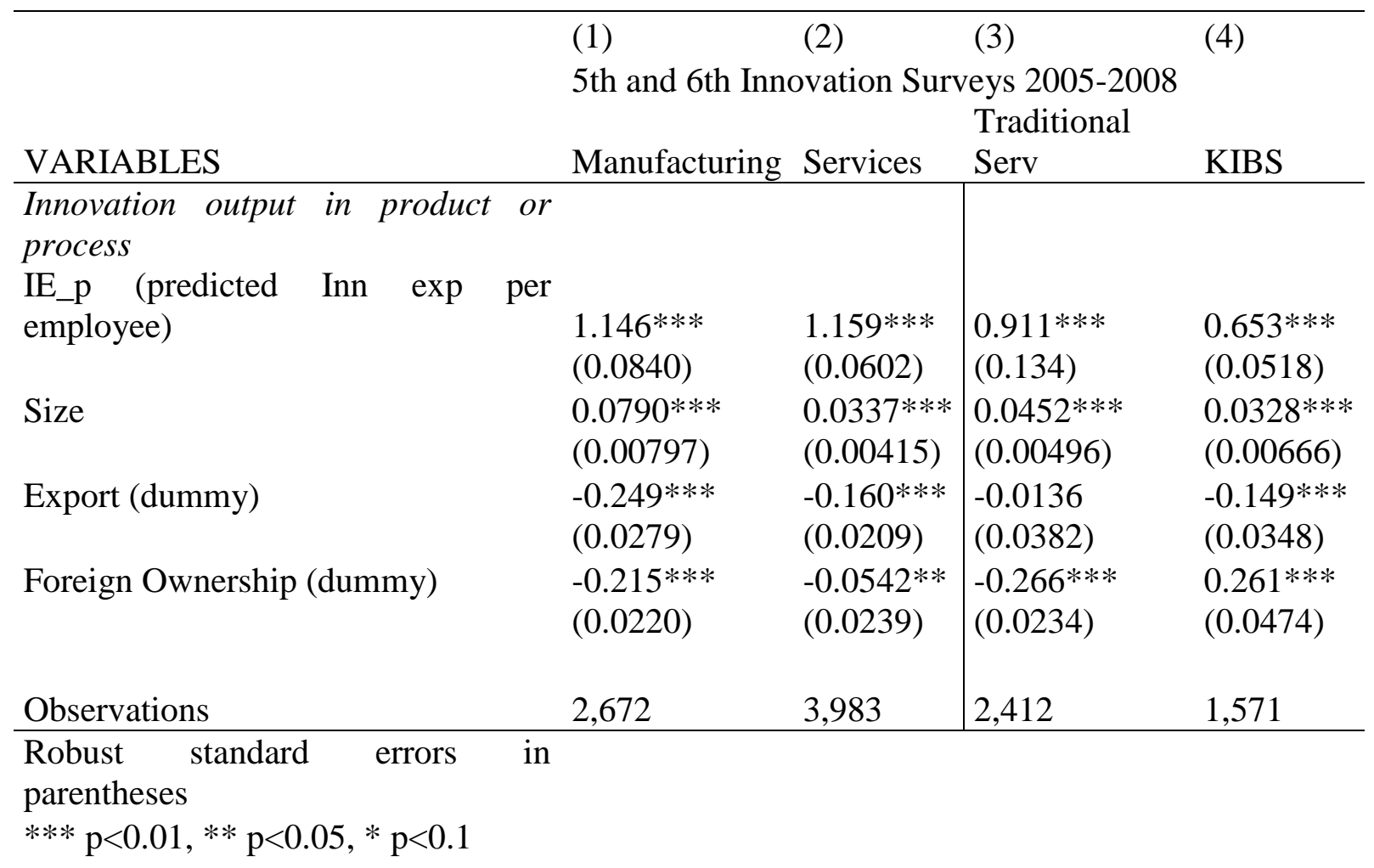

Finally in Table 17 we look at the output production function where we again incorporate the skill intensity as a covariate. In specification 1, the significance of the predicted value of innovating is unaltered. The coefficient of skill intensity is only significant for manufacturing in the output production function. When using the predicted value of innovation expenditures, its coefficient is now again significantly larger than the base scenario, but the inclusion of skills in both manufacturing and services appears not to be significant. Finally, we do not find important changes in coefficients when separating between KIBS and traditional services. The inclusion of skills in the output production function is not significant. 


\section{Table 17: Output Production Function}

Specification 1: using predicted probability of innovation output

without new equipment

\begin{tabular}{|c|c|c|c|c|}
\hline \multirow[b]{2}{*}{ VARIABLES } & (1) & (2) & (3) & (4) \\
\hline & \multicolumn{4}{|c|}{$\begin{array}{r}\text { 5th and 6th Innnovation Surveys 2005-2008 } \\
\text { Traditional }\end{array}$} \\
\hline \multicolumn{5}{|c|}{ log labor productivity (sales per worker) } \\
\hline TI_p (Technological innovation) & $\begin{array}{l}1.330^{* * * *} \\
(0.189)\end{array}$ & $\begin{array}{l}0.760 * * * \\
(0.149)\end{array}$ & $\begin{array}{l}2.233 * * * \\
(0.336)\end{array}$ & $\begin{array}{l}1.081 * * * \\
(0.210)\end{array}$ \\
\hline Size & $\begin{array}{l}-0.0126 \\
(0.0385)\end{array}$ & $\begin{array}{l}-0.323 * * * \\
(0.0167)\end{array}$ & $\begin{array}{l}-0.378^{* * *} \\
(0.0283)\end{array}$ & $\begin{array}{l}-0.372 * * * \\
(0.0255)\end{array}$ \\
\hline Skill intensity & $\begin{array}{l}1.128 * * \\
(0.466)\end{array}$ & $\begin{array}{l}-0.203 \\
(0.391)\end{array}$ & $\begin{array}{l}0.251 \\
(0.614)\end{array}$ & $\begin{array}{l}-0.600 \\
(0.467)\end{array}$ \\
\hline Constant & $\begin{array}{l}10.12^{* * *} \\
(0.115)\end{array}$ & $\begin{array}{l}12.92 * * * \\
(0.161)\end{array}$ & $\begin{array}{l}10.89 * * * \\
(0.109)\end{array}$ & $\begin{array}{l}11.51 * * * \\
(0.104)\end{array}$ \\
\hline Observations & 2,672 & 3,983 & 2,412 & 1,571 \\
\hline R-squared & 0.044 & 0.199 & 0.237 & 0.147 \\
\hline
\end{tabular}

Bootstrapped standard errors in parentheses

$* * * \mathrm{p}<0.01, * * \mathrm{p}<0.05, * \mathrm{p}<0.1$

Specification 2: using predicted innovation expenditure per employee

\begin{tabular}{lllll} 
VARIABLES & & & \\
\hline log labor productivity (sales per worker) & & & & \\
Size & -0.0252 & $-0.310^{* * *}$ & $-0.292^{* * *}$ & $-0.333^{* * *}$ \\
& $(0.0264)$ & $(0.0152)$ & $(0.0176)$ & $(0.0253)$ \\
IE_p (predicted Inn exp per employee) & 0.611 & -0.419 & 0.299 & -0.395 \\
& $(0.467)$ & $(0.421)$ & $(0.502)$ & $(0.505)$ \\
Skill intensity & $1.898^{* * *}$ & $1.248^{* * *}$ & $1.830^{* * *}$ & $0.417 * * *$ \\
& $(0.133)$ & $(0.130)$ & $(0.233)$ & $(0.123)$ \\
Constant & -1.219 & $4.994 * *$ & 1.723 & $8.928 * * *$ \\
& $(0.773)$ & $(0.834)$ & $(1.184)$ & $(0.816)$ \\
& & & & \\
Observations & 2,672 & 3,983 & 2,412 & 1,571 \\
R-squared & 0.102 & 0.206 & 0.254 & 0.139 \\
\hline
\end{tabular}

Bootstrapped standard errors in parentheses

$* * * \mathrm{p}<0.01, * * \mathrm{p}<0.05, * \mathrm{p}<0.1$ 
Overall, we expected that as size has a larger impact for innovation for manufacturing, skills might play a larger role in services innovation in Chile, in line with the empirical literature. We do not find that in the estimations above. Next we analyze the exact same regressions but incorporating skills in all stages. Due to its extension and redundancy we will not show the tables of this case (but they are available upon request). In the first stage, including skills in the intensity regression does not change results and the variable is not significant. When including skills in the knowledge production function, it enters the equation being highly significant, although with a negative sign, and decreases the coefficient size of the predicted value of innovation expenditure. But still the regressors remain significant and with the same signs as in Table 16. In the third stage we find more differences. In table 17 (specification 1) the coefficient of skills is positive and significant in manufacturing. That coefficient, when adding the variable in all stages, becomes negative and significant. Second size becomes significant and negative (it was non-significant in table 17). In the case of services the negative coefficient we observed in table 17 becomes significant.

Next, we try an alternative (better) definition of skill intensity: the percentage of employees that have a technical or professional degree. Unfortunately we only have data of this question for the $6^{\text {th }}$ innovation survey and thus we present results only for that. The first stage of the CDM model can be seen in Table 18 (we show the results of estimations where skills appear in all equations). The results are similar than what we have previously observed. Skill intensity is significant in both the selection equation and the intensity equation. However, again the coefficient is larger for manufacturing than for services. When controlling for skills, size is also relevant for both types of firms, but the coefficient is also larger for manufacturing. 
Table 18: Innovation Selection and Expenditure and Role of Skills

\begin{tabular}{|c|c|c|c|c|}
\hline \multirow[b]{3}{*}{ VARIABLES } & $(1)$ & (2) & (3) & (4) \\
\hline & \multicolumn{3}{|c|}{ 6th Innovation survey $2007-2008$} & \multirow[b]{2}{*}{ KIBS } \\
\hline & Manufacturing & Services & $\begin{array}{l}\text { Traditional } \\
\text { Serv }\end{array}$ & \\
\hline \multicolumn{5}{|c|}{$\begin{array}{l}\text { Selection (prob of spending in } \\
\text { innov) }\end{array}$} \\
\hline Exporting & $\begin{array}{l}0.0519 \\
(0.0333)\end{array}$ & $\begin{array}{l}0.0602 * \\
(0.0325)\end{array}$ & $\begin{array}{l}0.0519 \\
(0.0418)\end{array}$ & $\begin{array}{l}0.0813 \\
(0.0522)\end{array}$ \\
\hline Foreign & $\begin{array}{l}0.0193 \\
(0.0449)\end{array}$ & $\begin{array}{l}-0.0264 \\
(0.0277)\end{array}$ & $\begin{array}{l}-0.0261 \\
(0.0374)\end{array}$ & $\begin{array}{l}-0.0284 \\
(0.0412)\end{array}$ \\
\hline Size & $\begin{array}{l}0.0848 * * * \\
(0.0101)\end{array}$ & $\begin{array}{l}0.0441 * * * \\
(0.00405)\end{array}$ & $\begin{array}{l}0.0421 * * * \\
(0.00534)\end{array}$ & $\begin{array}{l}0.0455 * * * \\
(0.00663)\end{array}$ \\
\hline Patent Protection & $\begin{array}{l}0.405^{* * *} * \\
(0.102)\end{array}$ & $\begin{array}{l}0.482 * * * \\
(0.0895)\end{array}$ & $\begin{array}{l}0.533 * * * \\
(0.102)\end{array}$ & $\begin{array}{l}0.422 * * * \\
(0.155)\end{array}$ \\
\hline Skill intensity & $\begin{array}{l}0.217 * * * \\
(0.0474)\end{array}$ & $\begin{array}{l}0.0647 * * \\
(0.0269)\end{array}$ & $\begin{array}{l}-0.0127 \\
(0.0385)\end{array}$ & $\begin{array}{l}0.136 * * * \\
(0.0387)\end{array}$ \\
\hline $\begin{array}{l}\text { Intensity (log amount spend } \\
\text { employee) }\end{array}$ & in innov per & & & \\
\hline Exporting & $\begin{array}{l}0.965 * * * \\
(0.278)\end{array}$ & $\begin{array}{l}0.218 \\
(0.238)\end{array}$ & $\begin{array}{l}-0.150 \\
(0.315)\end{array}$ & $\begin{array}{l}0.655^{*} \\
(0.364)\end{array}$ \\
\hline Foreign & $\begin{array}{l}0.565^{*} \\
(0.309)\end{array}$ & $\begin{array}{l}0.131 \\
(0.299)\end{array}$ & $\begin{array}{l}0.423 \\
(0.356)\end{array}$ & $\begin{array}{l}-0.124 \\
(0.461)\end{array}$ \\
\hline Public financial support & $\begin{array}{l}0.601 \\
(0.433)\end{array}$ & $\begin{array}{l}0.637 * \\
(0.326)\end{array}$ & $\begin{array}{l}0.547 \\
(0.446)\end{array}$ & $\begin{array}{l}0.939 * \\
(0.550)\end{array}$ \\
\hline Patent Protection & $\begin{array}{l}0.240 \\
(0.462)\end{array}$ & $\begin{array}{l}0.593 \\
(0.377)\end{array}$ & $\begin{array}{l}0.513 \\
(0.432)\end{array}$ & $\begin{array}{l}0.543 \\
(0.738)\end{array}$ \\
\hline Co-operation in $\mathrm{R} \& \mathrm{D}$ & $\begin{array}{l}0.711 * * * \\
(0.249)\end{array}$ & $\begin{array}{l}0.318^{*} \\
(0.176)\end{array}$ & $\begin{array}{l}-0.0175 \\
(0.205)\end{array}$ & $\begin{array}{l}0.841 * * * \\
(0.301)\end{array}$ \\
\hline Market info sources (INFO1) & $\begin{array}{l}0.926 \\
(0.595)\end{array}$ & $\begin{array}{l}-0.0831 \\
(0.417)\end{array}$ & $\begin{array}{l}0.101 \\
(0.541)\end{array}$ & $\begin{array}{l}-0.398 \\
(0.669)\end{array}$ \\
\hline Scientific sources (INFO2) & $\begin{array}{l}-0.0708 \\
(0.799)\end{array}$ & $\begin{array}{l}0.258 \\
(0.603)\end{array}$ & $\begin{array}{l}0.635 \\
(0.672)\end{array}$ & $\begin{array}{l}-0.190 \\
(0.939)\end{array}$ \\
\hline Other spillovers (INFO3) & $\begin{array}{l}0.369 \\
(0.421)\end{array}$ & $\begin{array}{l}0.197 \\
(0.308)\end{array}$ & $\begin{array}{l}0.0730 \\
(0.421)\end{array}$ & $\begin{array}{l}0.520 \\
(0.451)\end{array}$ \\
\hline Skills intensity & $\begin{array}{l}1.103 * * \\
(0.471)\end{array}$ & $\begin{array}{l}0.998 * * * \\
(0.267)\end{array}$ & $\begin{array}{l}1.313 * * * \\
(0.330)\end{array}$ & $\begin{array}{l}0.657 \\
(0.408)\end{array}$ \\
\hline Observations & 1,265 & 2,627 & 1,543 & 1,084 \\
\hline
\end{tabular}

Robust standard errors in parentheses

$* * * \mathrm{p}<0.01, * * \mathrm{p}<0.05, * \mathrm{p}<0.1$ 
When comparing KIBS and traditional services, skill intensity appears only to be significant in the selection equation for KIBS and only significant in the intensity equation for traditional services. Table 19 shows the knowledge production function. As in the case of the use of the previous skill intensity variable, skills enters negatively and significant in this stage, which is counterintuitive, but may reflect the fact that skill is already entering through its effect on the expenditure on innovation.

Table 19: Knowledge Production Function

\begin{tabular}{|c|c|c|c|c|}
\hline & (1) & (2) & (3) & (4) \\
\hline & 6th Innovation & survey 2007 & -2008 & \\
\hline & & & Traditional & \\
\hline VARIABLES & Manufacturing & Services & Serv & KIBS \\
\hline Innovation output in product or & & & & \\
\hline IE_p (predicted Inn exp & & & & \\
\hline employee) & $1.226 * * *$ & $0.807 * * *$ & $0.500 * *$ & $0.630 * * *$ \\
\hline & $(0.245)$ & $(0.225)$ & $(0.214)$ & $(0.102)$ \\
\hline Size & $0.0445 * * *$ & $0.0293 * * *$ & $0.0320 * * *$ & $0.0338 * * *$ \\
\hline & $(0.0135)$ & $(0.00535)$ & $(0.00647)$ & $(0.00781)$ \\
\hline Export (dummy) & $-0.703 * * *$ & $-0.261 * * *$ & -0.00611 & $-0.313 * * *$ \\
\hline & $(0.0849)$ & $(0.0386)$ & $(0.0511)$ & $(0.0214)$ \\
\hline Foreign Ownership (dummy) & $-0.372 * * *$ & 0.0148 & $-0.139 * * *$ & $0.222 * * *$ \\
\hline & $(0.0475)$ & $(0.0320)$ & $(0.0468)$ & $(0.0631)$ \\
\hline Skills Intensity & $-2.205 * * *$ & $-1.130 * * *$ & $-0.651 * *$ & $-0.882 * * *$ \\
\hline & $(0.461)$ & $(0.324)$ & $(0.268)$ & $(0.162)$ \\
\hline Observations & 1,265 & 2,627 & 1,543 & 1,084 \\
\hline $\begin{array}{l}\text { Robust standard errors } \\
\text { parentheses } \\
* * * \mathrm{p}<0.01, * * \mathrm{p}<0.05, * \mathrm{p}<0.1\end{array}$ & & & & \\
\hline
\end{tabular}

The coefficients are similar for traditional and KIBS subsectors, however being larger for KIBS (including a larger negative coefficient for skills). Finally, we look at the output production function in Table 20. Skill intensity enters positively and significantly in both sectors, although its effect on labor productivity appears to be larger in services. This on top of a larger indirect effect through the predicted value of the probability of innovating, which has also a larger coefficient for services. These results are different from those obtained with the more restrictive definition of skill intensity. 


\section{Table 20: Output Production Function}

Specification 1: using predicted probability of innovation output

\begin{tabular}{|c|c|c|c|c|}
\hline \multirow[b]{2}{*}{ VARIABLES } & (1) & (2) & (3) & (4) \\
\hline & $\begin{array}{l}\text { 6th Innovation } \\
\text { Manufacturing }\end{array}$ & $\begin{array}{l}\text { urvey } 2007- \\
\text { Services }\end{array}$ & $\begin{array}{l}2008 \\
\text { Traditional } \\
\text { Serv }\end{array}$ & KIBS \\
\hline \multicolumn{5}{|c|}{ log labor productivity (sales per worker) } \\
\hline TI_p (Technological innovation) & $\begin{array}{l}0.734 * * * \\
(0.141)\end{array}$ & $\begin{array}{l}0.844 * * * \\
(0.265)\end{array}$ & $\begin{array}{l}1.230 * * * \\
(0.443)\end{array}$ & $\begin{array}{l}0.523 * * \\
(0.225)\end{array}$ \\
\hline Size & $\begin{array}{l}0.0310 \\
(0.0391)\end{array}$ & $\begin{array}{l}-0.349 * * * \\
(0.0195)\end{array}$ & $\begin{array}{l}-0.340 * * * \\
(0.0342)\end{array}$ & $\begin{array}{l}-0.365 * * * \\
(0.0275)\end{array}$ \\
\hline Skill intensity & $\begin{array}{l}0.635 * * * \\
(0.158)\end{array}$ & $\begin{array}{l}0.883 * * * \\
(0.0961)\end{array}$ & $\begin{array}{l}0.811 * * * \\
(0.150)\end{array}$ & $\begin{array}{l}0.963 * * * \\
(0.135)\end{array}$ \\
\hline Constant & $\begin{array}{l}10.09 * * * \\
(0.164)\end{array}$ & $\begin{array}{l}11.15^{* * *} \\
(0.139)\end{array}$ & $\begin{array}{l}11.05 * * * \\
(0.210)\end{array}$ & $\begin{array}{l}11.31 * * * \\
(0.146)\end{array}$ \\
\hline Observations & 1,265 & 2,627 & 1,543 & 1,084 \\
\hline R-squared & 0.052 & 0.267 & 0.284 & 0.243 \\
\hline
\end{tabular}

Bootstrapped standard errors in parentheses

$* * * \mathrm{p}<0.01, * * \mathrm{p}<0.05, * \mathrm{p}<0.1$

Specification 2: using predicted innovation expenditure per employee

\begin{tabular}{lllll} 
VARIABLES & & & \\
\hline log labor productivity (sales per worker) & & & & \\
Size & -0.0716 & $-0.327 * * *$ & $-0.307 * * *$ & $-0.356^{* * *}$ \\
& $(0.0468)$ & $(0.0201)$ & $(0.0303)$ & $(0.0289)$ \\
IE_p (predicted Inn exp per employee) & $-0.554^{* *}$ & $0.329 * *$ & 0.113 & $0.529 * *$ \\
& $(0.227)$ & $(0.162)$ & $(0.312)$ & $(0.211)$ \\
Skill intensity & $0.588^{* * *}$ & $0.383 * * *$ & $0.507 * * *$ & $0.299 * * *$ \\
& $(0.0698)$ & $(0.0935)$ & $(0.172)$ & $(0.0987)$ \\
Constant & $8.694 * * *$ & $10.37 * * *$ & $9.826 * * *$ & $10.61 * * *$ \\
& $(0.135)$ & $(0.257)$ & $(0.363)$ & $(0.288)$ \\
& & & & \\
Observations & 1,265 & 2,627 & 1,543 & 1,084 \\
R-squared & 0.127 & 0.269 & 0.287 & 0.247 \\
\hline
\end{tabular}

Bootstrapped standard errors in parentheses

$* * * \mathrm{p}<0.01, * * \mathrm{p}<0.05, * \mathrm{p}<0.1$ 
Finally, we make an attempt to exogenize the skill intensity variable by using instrumental variables through a two-stage regression. We will use the average skill intensity of the region ${ }^{17}$ where the firm is located, while excluding the ISIC sector of the firm, as an instrument of skill intensity. We assume here that skills of the firm are correlated with average skill availability in the region but does not affect it by excluding the ISIC sector form the calculation. We then regress the skill intensity of each firm on the artificially created variable and then use the predicted value as instrument.

Table 21 shows first the initial regression to obtain the part of skills explained only by regional average skills of other sectors. There is a (weak) positive correlation between skills in the region and the firm skill intensity. Nevertheless we will analyze its impact in the CDM model.

Table 21.

(1)

VARIABLES

Skills Variable Instrumental

skills in the region excl ISIC

$0.307^{*}$

$(0.157)$

Constant

$0.00777^{\star \star \star}$

(0.00186)

Observations $\quad 6,655$

R-squared $\quad 0.001$

Standard errors in parentheses

${ }^{* * *} p<0.01,{ }^{* *} p<0.05,{ }^{*} p<0.1$

Table 22 shows that the skills instrumental variable is not significant in explaining the probability of spending in innovation in neither sector. Obviously this could be the case because the instrument is not a good one.

\footnotetext{
${ }^{17}$ Chile has 15 different regions across the country, where firms can be located.
} 
Table 22. Innovation Selection and Expenditure and Role of Skills

(1)

(2)

5th and 6th Innovation Surveys 2005-2008

VARIABLES
Selection (prob of spending in

innov)

Exporting

$0.0815 * * * \quad 0.0598 * *$

$(0.0232) \quad(0.0285)$

Foreign

0.0170

0.0111

$(0.0307)$

$(0.0244)$

Size

$0.0992 * * *$

$0.0558 * * *$

$(0.00733)$

$(0.00331)$

Patent Protection

$0.339 * * *$

$0.274 * * *$

(0.0544)

(0.0566)

Skill intensity

$-4.816$

1.285

(5.235)

(4.340)

\begin{tabular}{lll}
\hline Intensity (log amount spend in innov & per employee) & \\
Exporting & $0.681^{* * *}$ & $0.391^{*}$ \\
& $(0.156)$ & $(0.200)$ \\
Foreign & 0.306 & 0.0906 \\
& $(0.195)$ & $(0.234)$ \\
Public financial support & 0.261 & $0.424 *$ \\
& $(0.216)$ & $(0.226)$ \\
Patent Protection & 0.147 & $0.489 *$ \\
& $(0.221)$ & $(0.253)$ \\
Co-operation in R\&D & $0.481 * * *$ & $0.627 * * *$ \\
& $(0.140)$ & $(0.126)$ \\
Market info sources (INFO1) & -0.114 & 0.0921 \\
& $(0.174)$ & $(0.175)$ \\
Scientific sources (INFO2) & 0.000544 & -0.120 \\
& $(0.102)$ & $(0.102)$ \\
Other spillovers (INFO3) & 0.0465 & -0.0219 \\
& $(0.148)$ & $(0.130)$
\end{tabular}

Observations

2,666

3,983

Robust standard errors in

parentheses

$* * * \mathrm{p}<0.01, * * \mathrm{p}<0.05, * \mathrm{p}<0.1$

Table 23 finally shows the output production function (we skip the knowledge production function simply to show the coefficient and significance of the skill intensity IV). Skills only appear to be significant for the case of the services sector. 


\section{Table 23: Output Production Function}

Specification 1: using predicted probability of innovation output

\begin{tabular}{lll}
\hline & $(1)$ & $(2)$ \\
& 5 th and 6th & Innovation Surveys 2005- \\
& 2008 & \\
VARIABLES & Manufacturing & Services \\
\hline log labor productivity (sales per worker) & & \\
TI_p (Technological innovation) & $1.312^{* * *}$ & $0.879 * * *$ \\
& $(0.188)$ & $(0.165)$ \\
Size & -0.0114 & $-0.348^{* * *}$ \\
& $(0.0323)$ & $(0.0178)$ \\
Skill intensity & 19.38 & $181.3 * * *$ \\
& $(16.16)$ & $(19.44)$ \\
Constant & $9.935^{* * *}$ & $11.00 * * *$ \\
& $(0.187)$ & $(0.295)$ \\
Observations & & 3,983 \\
R-squared & 2,672 & 0.220 \\
\hline
\end{tabular}

Bootstrapped standard errors in parentheses

$* * * \mathrm{p}<0.01, * * \mathrm{p}<0.05, * \mathrm{p}<0.1$

Summarizing, even though the recent empirical literature give a more important role to skills in the services sector, we do not find robust evidence of such a differential role. Depending on the definition of skills we use and the stages in which we believe it might be relevant we find some cases in which skills appear as more significant in manufacturing and in other cases in services. Skills appear to be more relevant for KIBS when compared to traditional services, but not when compared to manufacturing.

\section{c) Non-Technological Innovation}

In a third and final extension, we will test specifications with non-technological innovation as dependent variable. In Crespi and Zúñiga (2011) this type of innovation only appears as explanatory variable in the productivity estimation. Non-technological innovation has been reported to be much more important in services than manufacturing (DTI (2007); Pires et 
al. (2008). We estimate the probability of introducing non-technological innovations as well as technological innovations and assess its importance in a labor productivity regression. Nontechnological innovation is defined as the probability of introducing marketing, design, distribution or management innovations.

We present results for the $2^{\text {nd }}$ and $3^{\text {rd }}$ stage of the CDM model, since the first stage is exactly the same as the base estimation of Table 8 . Table 24 shows the estimation for the probability of introducing non-technological innovations and the impact of the expenditure in innovation as well as other covariates. It is an identical regression as Table 9, but where the dependent variable is non-technological innovation instead of technological innovation.

Table 24: Knowledge Production Function for Non-technological Innovation (probit marginal effects shown)

\begin{tabular}{lcc|cc}
\hline & $(1)$ & $(2)$ & $(3)$ & $(4)$ \\
VARIABLES & \multicolumn{2}{c}{ 5th and 6 th } & \multicolumn{2}{c}{ Innnovation Surveys 2005-2008 } \\
\hline Non-technological innovation output & & & & \\
IE_p (predicted Inn exp per employee) & $0.607^{* * *}$ & $0.402^{* * *}$ & $0.0725^{* *}$ & $0.436^{* * *}$ \\
& $(0.0551)$ & $(0.0423)$ & $(0.0342)$ & $(0.0472)$ \\
Size & $0.0537^{* * *}$ & $0.0342^{* * *}$ & $0.0486^{* * *}$ & $0.0234^{* * *}$ \\
& $(0.00730)$ & $(0.00399)$ & $(0.00493)$ & $(0.00653)$ \\
Export (dummy) & $-0.385^{* * *}$ & $-0.182^{* * *}$ & 0.0268 & $-0.248^{* * *}$ \\
& $(0.0323)$ & $(0.0247)$ & $(0.0418)$ & $(0.0277)$ \\
Foreign Ownership (dummy) & $-0.189^{* * *}$ & $-0.0879^{* * *}$ & -0.0455 & 0.0629 \\
& $(0.0220)$ & $(0.0220)$ & $(0.0349)$ & $(0.0438)$ \\
& & & & \\
Observations & 2,672 & 3,983 & 2,412 & 1,571 \\
\hline
\end{tabular}

Robust standard errors in parentheses

*** $p<0.01,{ }^{* *} p<0.05, * p<0.1$

Results are very similar to those of technological innovation in Table 9. The predicted value of innovation expenditure (which is mostly for technological purposes) has a strikingly similar impact in non-technological innovation, albeit a little smaller in the service sector. The (positive) impact of size and that of export status and foreign ownership (both negative) are also very similar to those of table 8 . These very similar results might be due to the fact that technological and non-technological innovation appear to be very correlated.

When we disaggregate services between traditional and KIBS we again observe that the coefficient of innovation expenditure is larger for KIBS, although both coefficients are smaller 
when compared to the coefficients of the same variable on technological innovation. The opposite signs of foreign ownership remain for non-technological innovation, although they stop being significant.

To finalize, we show the output production function using the predicted probability of introducing non-technological innovations to analyze its impact on productivity. This can be seen in Table 25.

Table 25: Output Production Function for Non-technological Innovation Specification 1: using predicted probability of non-tech innovation whitout new equipment

\begin{tabular}{lcccc}
\hline & $(1)$ & $(2)$ & $(3)$ & $(4)$ \\
& \multicolumn{2}{c}{5 th and 6 th Innnovation Surveys 2005-2008 } \\
VARIABLES & Manufacturing & Services & Traditional Serv & KIBS \\
\hline log labor productivity (sales per worker) & & & & \\
TI_p (non-technological innovation) & $1.281^{* * *}$ & $0.958^{* * *}$ & $7.989^{* * *}$ & $0.782^{* * *}$ \\
& $(0.176)$ & $(0.177)$ & $(1.062)$ & $(0.199)$ \\
Size & 0.0186 & $-0.329^{* * *}$ & $-0.669 * * *$ & $-0.351^{* * *}$ \\
& $(0.0280)$ & $(0.0186)$ & $(0.0575)$ & $(0.0228)$ \\
Constant & $10.09^{* * *}$ & $12.90^{* * *}$ & $10.98^{* * *}$ & $11.57^{* * *}$ \\
& $(0.0915)$ & $(0.121)$ & $(0.115)$ & $(0.110)$ \\
& & & & \\
Observations & 2,672 & 3,983 & 2,412 & 1,571 \\
R-squared & 0.038 & 0.198 & 0.243 & 0.141 \\
\hline Bootstrapped standard errors in parentheses & & & \\
$* * * p<0.01, * * p<0.05, * p<0.1$ & & & &
\end{tabular}

Results are again similar to Table 10 (using technological innovation), although the impact of non-technological innovation in productivity in services is larger than the effect of technological innovation. The opposite can be said for manufacturing (although the difference with Table 10 is minimal). Decomposing the effect between KIBS and traditional services shows that the larger effect of non-technological innovation appears to be mostly driven by traditional services given that the coefficient is not only one order of magnitude larger than for KIBS, but it is double the size of the effect of technological innovation in labor productivity as seen in Table 10. 


\section{Conclusions}

In this study we have performed an extensive analysis of innovation inputs, output, and impact in labor productivity of the services sector in Chile, while comparing it to manufacturing as a benchmark. Using the $5^{\text {th }}$ and $6^{\text {th }}$ innovation surveys (2005-2008) we found that while being significantly less export oriented the services sector innovates as much as manufacturing both in technological and non-technological types of innovation output, and for both sector both types of innovation appear as important determinants of labor productivity. The variables analyzed as determinants for innovation inputs and outputs appear to be relevant in both sectors, with some variation across them. Firm size is a more significant determinant of innovation expenditure and the probability of producing a new product, service or process. Skills, which has been found to be a more important variable for services firms also appears to be relatively more important in manufacturing.

Overall even though we observe similar innovative behavior in both sectors, it might be the case that we are observing variables and outcomes more related to technological innovation, which is well known to be more critical for manufacturing. What is interesting is that while playing on the manufacturing "field", services firms show similar innovation intensities, determinants and impact of innovation on labor productivity. Also, these results might indicate that other variables, not measured in a traditional innovation survey, might be more relevant for the services industry, and that innovation surveys should maybe start incorporating a more clearcut and less discrete non-technological view. 


\section{Appendix 1: Alternative Estimations for Robustness (base scenario)}

\section{A. Base Scenario Estimations with Weights}

As a robustness check we provide the same original estimations of Tables 8-10 using the weights provided by the innovations surveys. Table A1 shows the selection and intensity regressions for the expenditure in innovation.

Table A1: First Stage Estimation of Probability and Intensity of Innovation Expenditure (using weights, marginal effects shown)

\begin{tabular}{|c|c|c|c|c|}
\hline \multirow[b]{3}{*}{ VARIABLES } & (1) & $(2)$ & (3) & (4) \\
\hline & \multicolumn{4}{|c|}{ 5th and 6th Innnovation Surveys 2005-2008 } \\
\hline & Manufacturing & Services & Traditional Serv & KIBS \\
\hline \multicolumn{5}{|c|}{ Selection (prob of spending in innov) } \\
\hline Exporting & $\begin{array}{c}0.0983 * * * \\
(0.0332)\end{array}$ & $\begin{array}{c}0.140 \\
(0.128)\end{array}$ & $\begin{array}{c}0.127 \\
(0.146)\end{array}$ & $\begin{array}{c}0.157^{*} \\
(0.0863)\end{array}$ \\
\hline Foreign & $\begin{array}{c}0.0285 \\
(0.0426)\end{array}$ & $\begin{array}{c}0.0157 \\
(0.0965)\end{array}$ & $\begin{array}{l}0.0246 \\
(0.114)\end{array}$ & $\begin{array}{c}-0.0207 \\
(0.116)\end{array}$ \\
\hline Size & $\begin{array}{c}0.0864^{* * * *} \\
(0.0103)\end{array}$ & $\begin{array}{c}0.0470 * * * \\
(0.00956)\end{array}$ & $\begin{array}{c}0.0358 * * * \\
(0.00909)\end{array}$ & $\begin{array}{c}0.0749 * * * \\
(0.0165)\end{array}$ \\
\hline Patent Protection & $\begin{array}{c}0.334^{* * *} \\
(0.0762)\end{array}$ & $\begin{array}{l}0.0144 \\
(0.133)\end{array}$ & $\begin{array}{c}-0.00397 \\
(0.147)\end{array}$ & $\begin{array}{c}-0.00126 \\
(0.0826)\end{array}$ \\
\hline \multicolumn{5}{|c|}{ Intensity (log amount spend in innov per employee) } \\
\hline Exporting & $\begin{array}{c}0.679 * * * \\
(0.182)\end{array}$ & $\begin{array}{l}-0.206 \\
(0.377)\end{array}$ & $\begin{array}{c}-0.600^{*} \\
(0.352)\end{array}$ & $\begin{array}{c}0.276 \\
(0.447)\end{array}$ \\
\hline Foreign & $\begin{array}{c}0.323 \\
(0.261)\end{array}$ & $\begin{array}{c}0.528 * * \\
(0.268)\end{array}$ & $\begin{array}{c}0.541^{* *} \\
(0.260)\end{array}$ & $\begin{array}{c}0.140 \\
(0.553)\end{array}$ \\
\hline Public financial support & $\begin{array}{c}0.272 \\
(0.219)\end{array}$ & $\begin{array}{c}1.432 * * \\
(0.573)\end{array}$ & $\begin{array}{c}0.863 * * \\
(0.404)\end{array}$ & $\begin{array}{l}1.382 * * \\
(0.689)\end{array}$ \\
\hline Patent Protection & $\begin{array}{c}0.298 \\
(0.356)\end{array}$ & $\begin{array}{l}0.0359 \\
(0.708)\end{array}$ & $\begin{array}{l}-0.252 \\
(0.547)\end{array}$ & $\begin{array}{c}1.979 * * \\
(0.857)\end{array}$ \\
\hline Co-operation in R\&D & $\begin{array}{c}0.676^{* * *} \\
(0.178)\end{array}$ & $\begin{array}{l}0.0512 \\
(0.290)\end{array}$ & $\begin{array}{l}-0.341 \\
(0.311)\end{array}$ & $\begin{array}{c}1.230 * * * \\
(0.473)\end{array}$ \\
\hline Market info sources (INFO1) & $\begin{array}{c}0.167 \\
(0.203)\end{array}$ & $\begin{array}{l}-0.353 \\
(0.429)\end{array}$ & $\begin{array}{l}-0.569 \\
(0.366)\end{array}$ & $\begin{array}{l}-0.268 \\
(0.781)\end{array}$ \\
\hline Scientific sources (INFO2) & $\begin{array}{c}-0.0760 \\
(0.134)\end{array}$ & $\begin{array}{l}-0.0463 \\
(0.242)\end{array}$ & $\begin{array}{c}0.282 \\
(0.261)\end{array}$ & $\begin{array}{c}-0.590^{*} \\
(0.346)\end{array}$ \\
\hline Other spillovers (INFO3) & $\begin{array}{c}-0.0550 \\
(0.177)\end{array}$ & $\begin{array}{c}0.00259 \\
(0.255)\end{array}$ & $\begin{array}{c}-0.510^{* *} \\
(0.241)\end{array}$ & $\begin{array}{c}0.653 \\
(0.578)\end{array}$ \\
\hline Observations & 2679 & 3985 & 2,413 & 1,572 \\
\hline
\end{tabular}

Robust standard errors in parentheses

$* * * p<0.01, * * p<0.05, * p<0.1$ 
Comparing Table A1 with Table 8, the most important differences can be appreciated in the service sector. In the selection equation, exporting and patent protection do not appear to be significant determinants of the probability of spending in innovation in the service sector, unlike Table 8 . Moreover, in the intensity equation exporting becomes non-significant too and changes sign; foreign participation becomes significant and increases its coefficient, indicating that foreign capital shows an effect in the extent of expenditure more than in the probability of spending. Public support becomes 3 times as important as in the unweighted regression and patent protection and cooperation lose their significance. The results for the manufacturing sector do not change significantly. When disaggregating between KIBS and traditional services, patent protection again loses its significance in both and moreover changes sign and becomes negative. In the intensity equation, the loss of significance of exporting seems driven by traditional services, which now show a negative and marginally significant (at 10 percent level) coefficient. The significance of the coefficient of foreign capital again seems driven by the traditional services, which is now significant and was not in the version without weights. Patent protection loses significance because of netting of a negative coefficient (although not significant) for traditional services and a large positive and significant coefficient for KIBS. Patent protection here appear very relevant for the KIBS sector to increase the expenditure in innovation. Something similar can be observed for cooperation in R\&D. The coefficient with weights losses significance in services because the coefficient for the traditional services sector changes sign and becomes negative (and not significant), whereas the KIBS sector shows a highly positive and significant coefficient.

Overall, these differing results with the unweighted regressions suggest we should be careful with the conclusions taken with part of the variables analyzed in the main text, particularly regarding the services sector. Second, we show the knowledge production function in Table A2. 
Table A2: $2^{\text {nd }}$ Stage Estimation: Probability of Innovating in Products, Services or Processes (probit marginal effects shown, using weights)

\begin{tabular}{lcccc}
\hline & $(1)$ & $(2)$ & $(3)$ & $(4)$ \\
& \multicolumn{2}{c}{ 5th and 6th } & \multicolumn{2}{c}{ Innnovation Surveys 2005-2008 } \\
VARIABLES & Manufacturing & Services & \multicolumn{1}{c}{ Traditional Serv } & KIBS \\
\hline Innovation output in product or process & & & & \\
IE_p (predicted Inn exp per employee) & $0.505^{* * *}$ & $-0.252^{* *}$ & $-0.600^{* * *}$ & $0.206^{* * *}$ \\
& $(0.0605)$ & $(0.124)$ & $(0.115)$ & $(0.0529)$ \\
Size & $0.0600^{* * *}$ & $0.0347^{* * *}$ & 0.0209 & $0.0547^{* * *}$ \\
& $(0.0108)$ & $(0.0123)$ & $(0.0144)$ & $(0.0158)$ \\
Export (dummy) & $-0.335^{* * *}$ & $0.382^{*}$ & 0.285 & $-0.125^{* *}$ \\
& $(0.0394)$ & $(0.195)$ & $(0.190)$ & $(0.0522)$ \\
Foreign Ownership (dummy) & $-0.163^{* * *}$ & 0.210 & $0.566^{* * *}$ & -0.00103 \\
& $(0.0310)$ & $(0.181)$ & $(0.181)$ & $(0.0980)$ \\
& & & & \\
Observations & 2,679 & 3,985 & 2,413 & 1,572 \\
\hline
\end{tabular}

Robust standard errors in parentheses

$* * * p<0.01, * * p<0.05, * p<0.1$

The second stage also shows robustness for the results for manufacturing in table 9, but different results for the services sector, mostly apparently driven by different coefficients from the traditional services sector.

Finally, Table A3 compares the production function with that of table 10. 


\section{Table A3: Production Function}

Specification 1: using predicted probability of innovation output

whitout new equipment

\begin{tabular}{lcccc}
\hline & $(1)$ & $(2)$ & $(3)$ & $(4)$ \\
& \multicolumn{2}{c}{ 5th and 6th Innnovation Surveys 2005-2008 } \\
VARIABLES & Manufacturing & Services & Traditional Serv & KIBS \\
\hline log labor productivity (sales per worker) & & & & \\
TI_p (Technological innovation) & $1.314^{* * *}$ & $1.544^{* * *}$ & 0.0477 & $1.305^{* * *}$ \\
& $(0.147)$ & $(0.379)$ & $(0.127)$ & $(0.238)$ \\
Size & -0.00758 & $-0.352^{* * *}$ & $-0.265^{* * *}$ & $-0.420^{* * *}$ \\
& $(0.0356)$ & $(0.0213)$ & $(0.0194)$ & $(0.0349)$ \\
New Equipment & & & & \\
& & & & \\
Constant & $10.17^{* * *}$ & $12.75^{* * *}$ & $10.94^{* * *}$ & $11.57^{* * *}$ \\
& $(0.115)$ & $(0.173)$ & $(0.110)$ & $(0.105)$ \\
& & & & \\
Observations & 2,679 & 3,985 & 2,413 & 1,572 \\
R-squared & 0.048 & 0.197 & 0.228 & 0.148 \\
\hline
\end{tabular}

Bootstrapped standard errors in parentheses

$* * * p<0.01, * * p<0.05, * p<0.1$

We show only specification 1 and without the new equipment. Again, results are similar as the base estimation for manufacturing. Interestingly, also the coefficients for the service sector are not altered much when we use weights. However, again for the traditional services subsector the coefficient for the predicted value of the probability of innovating decreases dramatically and becomes insignificant.

\section{B. Base Scenario Estimations using $4^{\text {th }}-7^{\text {th }}$ Pooled Innovation Surveys}

As a second robustness check on the results we add the base model (and we disaggregate for KIBS and non-KIBS subindustries) using the 4 datasets on innovation surveys we have available. Table B1 shows the results of the first stage. 
Table B1: Innovation Investment Selection and Intensity Equation, $4^{\text {th }}-7^{\text {th }}$ Innovation Surveys

\begin{tabular}{|c|c|c|c|c|c|c|c|c|}
\hline \multirow[b]{4}{*}{ VARIABLES } & \multicolumn{4}{|c|}{ unweighted } & \multicolumn{4}{|c|}{ weighted } \\
\hline & (1) & (2) & (3) & (4) & $(1)$ & $(2)$ & (3) & (4) \\
\hline & \multicolumn{4}{|c|}{ 4th, 5th, 6th and 7th Inn Surveys 2003-2010 } & \multicolumn{4}{|c|}{ 4th, 5th, 6th and 7th Inn Surveys 2003-2010 } \\
\hline & Manufacturing & Services & Traditional Serv & KIBS & Manufacturing & Services & Traditional Serv & KIBS \\
\hline \multicolumn{9}{|c|}{ Selection (prob of spending in innov) } \\
\hline Exporting & $\begin{array}{c}0.118 * * * \\
(0.0164)\end{array}$ & $\begin{array}{c}0.0859 * * * \\
(0.0210)\end{array}$ & $\begin{array}{c}0.0831^{* * *} \\
(0.0285)\end{array}$ & $\begin{array}{c}0.0942^{* * *} \\
(0.0308)\end{array}$ & $\begin{array}{c}0.123 * * * \\
(0.0230)\end{array}$ & $\begin{array}{c}0.0300 \\
(0.0571)\end{array}$ & $\begin{array}{c}0.0281 \\
(0.0718)\end{array}$ & $\begin{array}{c}0.0797 \\
(0.0656)\end{array}$ \\
\hline Foreign & $\begin{array}{c}0.0885^{* * *} \\
(0.0156)\end{array}$ & $\begin{array}{c}0.0197 \\
(0.0130)\end{array}$ & $\begin{array}{c}-0.00955 \\
(0.0176)\end{array}$ & $\begin{array}{l}0.0343^{*} \\
(0.0194)\end{array}$ & $\begin{array}{c}0.0642^{* * *} \\
(0.0234)\end{array}$ & $\begin{array}{c}-0.00780 \\
(0.0344)\end{array}$ & $\begin{array}{l}-0.0279 \\
(0.0484)\end{array}$ & $\begin{array}{l}0.00636 \\
(0.0364)\end{array}$ \\
\hline Size & $\begin{array}{c}0.0877^{* * *} \\
(0.00498)\end{array}$ & $\begin{array}{l}0.0583^{* * *} \\
(0.00235)\end{array}$ & $\begin{array}{c}0.0518 * * * \\
(0.00321)\end{array}$ & $\begin{array}{c}0.0615^{* * *} \\
(0.00355)\end{array}$ & $\begin{array}{c}0.0790 * * * \\
(0.00703)\end{array}$ & $\begin{array}{c}0.0418^{* * *} \\
(0.00572)\end{array}$ & $\begin{array}{c}0.0318^{* * *} \\
(0.00609)\end{array}$ & $\begin{array}{r}0.0607 * * * \\
(0.00873)\end{array}$ \\
\hline Patent Protection & $\begin{array}{c}-0.0637^{* * *} \\
(0.0163)\end{array}$ & $\begin{array}{c}-0.0221^{* *} \\
(0.0111)\end{array}$ & $\begin{array}{c}-0.00204 \\
(0.0158)\end{array}$ & $\begin{array}{c}-0.0493 * * * \\
(0.0169)\end{array}$ & $\begin{array}{l}-0.0228 \\
(0.0253)\end{array}$ & $\begin{array}{c}-0.0654^{* * *} \\
(0.0247)\end{array}$ & $\begin{array}{l}-0.0528 \\
(0.0347)\end{array}$ & $\begin{array}{c}-0.0917^{* * *} \\
(0.0305)\end{array}$ \\
\hline \multicolumn{9}{|c|}{ Intensity (log amount spend in innov per employee) } \\
\hline Exporting & $\begin{array}{c}0.458^{* * *} \\
(0.104)\end{array}$ & $\begin{array}{c}0.455^{* * *} \\
(0.155)\end{array}$ & $\begin{array}{l}0.387^{*} \\
(0.217)\end{array}$ & $\begin{array}{c}0.484^{* *} \\
(0.222)\end{array}$ & $\begin{array}{c}0.565^{* * *} \\
(0.142)\end{array}$ & $\begin{array}{l}0.207 \\
(0.394)\end{array}$ & $\begin{array}{l}-0.295 \\
(0.442)\end{array}$ & $\begin{array}{l}0.197 \\
(0.610)\end{array}$ \\
\hline Foreign & $\begin{array}{l}0.188^{*} \\
(0.101)\end{array}$ & $\begin{array}{l}0.0432 \\
(0.111)\end{array}$ & $\begin{array}{l}-0.0512 \\
(0.158)\end{array}$ & $\begin{array}{l}0.0861 \\
(0.162)\end{array}$ & $\begin{array}{c}-0.0869 \\
(0.164)\end{array}$ & $\begin{array}{l}0.0932 \\
(0.248)\end{array}$ & $\begin{array}{l}0.00960 \\
(0.262)\end{array}$ & $\begin{array}{c}-0.0963 \\
(0.341)\end{array}$ \\
\hline Public financial support & $\begin{array}{c}0.329 * * \\
(0.138)\end{array}$ & $\begin{array}{c}0.154 \\
(0.163)\end{array}$ & $\begin{array}{l}-0.196 \\
(0.232)\end{array}$ & $\begin{array}{c}0.565^{* *} \\
(0.238)\end{array}$ & $\begin{array}{l}0.0977 \\
(0.250)\end{array}$ & $\begin{array}{c}0.749 * * \\
(0.379)\end{array}$ & $\begin{array}{c}0.250 \\
(0.454)\end{array}$ & $\begin{array}{c}1.231^{* *} \\
(0.570)\end{array}$ \\
\hline Patent Protection & $\begin{array}{c}0.102 \\
(0.121)\end{array}$ & $\begin{array}{l}-0.0819 \\
(0.101)\end{array}$ & $\begin{array}{l}-0.174 \\
(0.152)\end{array}$ & $\begin{array}{c}-0.0137 \\
(0.153)\end{array}$ & $\begin{array}{c}-0.321^{*} \\
(0.184)\end{array}$ & $\begin{array}{l}0.0714 \\
(0.208)\end{array}$ & $\begin{array}{l}-0.196 \\
(0.257)\end{array}$ & $\begin{array}{c}0.271 \\
(0.323)\end{array}$ \\
\hline Co-operation in R\&D & $\begin{array}{c}0.455^{* * *} \\
(0.105)\end{array}$ & $\begin{array}{c}0.664 * * * \\
(0.0956)\end{array}$ & $\begin{array}{c}0.308^{* *} \\
(0.148)\end{array}$ & $\begin{array}{c}0.898 * * * \\
(0.136)\end{array}$ & $\begin{array}{c}0.602^{* * *} \\
(0.167)\end{array}$ & $\begin{array}{l}0.0949 \\
(0.259)\end{array}$ & $\begin{array}{c}-0.642 * * \\
(0.253)\end{array}$ & $\begin{array}{c}1.319 * * * \\
(0.319)\end{array}$ \\
\hline Market info sources (INFO1) & $\begin{array}{c}-0.0595 \\
(0.138)\end{array}$ & $\begin{array}{l}0.0298 \\
(0.139)\end{array}$ & $\begin{array}{l}0.0118 \\
(0.208)\end{array}$ & $\begin{array}{c}-0.0824 \\
(0.201)\end{array}$ & $\begin{array}{c}0.120 \\
(0.217)\end{array}$ & $\begin{array}{c}-0.606^{*} \\
(0.349)\end{array}$ & $\begin{array}{l}-0.375 \\
(0.343)\end{array}$ & $\begin{array}{c}-0.923^{*} \\
(0.544)\end{array}$ \\
\hline Scientific sources (INFO2) & $\begin{array}{c}0.0279 \\
(0.0888)\end{array}$ & $\begin{array}{c}-0.130 \\
(0.0886)\end{array}$ & $\begin{array}{l}-0.118 \\
(0.145)\end{array}$ & $\begin{array}{l}-0.113 \\
(0.116)\end{array}$ & $\begin{array}{l}-0.114 \\
(0.138)\end{array}$ & $\begin{array}{c}0.218 \\
(0.196)\end{array}$ & $\begin{array}{c}0.115 \\
(0.246)\end{array}$ & $\begin{array}{c}0.131 \\
(0.298)\end{array}$ \\
\hline Other spillovers (INFO3) & $\begin{array}{l}-0.0530 \\
(0.126)\end{array}$ & $\begin{array}{c}-0.000314 \\
(0.110)\end{array}$ & $\begin{array}{l}-0.0438 \\
(0.165)\end{array}$ & $\begin{array}{l}0.0796 \\
(0.155)\end{array}$ & $\begin{array}{c}-0.0345 \\
(0.172)\end{array}$ & $\begin{array}{l}-0.400^{*} \\
(0.227)\end{array}$ & $\begin{array}{c}-0.709 * * * \\
(0.273)\end{array}$ & $\begin{array}{l}-0.105 \\
(0.383)\end{array}$ \\
\hline Observations & 4,928 & 7,689 & 3,765 & 3,443 & 5,005 & 7,689 & 3,765 & 3,443 \\
\hline
\end{tabular}

Robust standard errors in parentheses

$* * * p<0.01, * * p<0.05, * p<0.1$

Comparing first the unweighted databases, we find that results are very similar with the base scenario in the main text. The only difference being the impact of patent protection on the decision to spend, which with the 4 innovation surveys together changes sign and becomes negative and significant, something which is counterintuitive. When disaggregating the services industries in KIBS and traditional services, we again observe differences in the traditional services sector, where exporting becomes a significant correlate of the probability of investing in innovation, and where patent protection loses significance and actually changes sign, becoming negative. Differences in the intensity equation are minimal.

Now we look at the weighted pooled cross section. As in the case of the weighted pool of the $5^{\text {th }}$ and $6^{\text {th }}$ surveys, when adding the $4^{\text {th }}$ and $7^{\text {th }}$, we also observe that exporting becomes insignificant in explaining the probability of spending on innovation. Foreign participation is now only significant in manufacturing (it was not significant in neither the base estimation and in the weighted $5^{\text {th }}$ and $6^{\text {th }}$ ). Here too patent protection change sign and become significant in the case of services, consistent with what happened with the unweighted $4^{\text {th }}-7^{\text {th }}$ pool. For the 
intensity specification, again for services we observe relevance for public financial support, as in the original model and the its weighted version. Market information sources and other spillovers become negative when comparing with the original model and are now significant at the 10 percent level. Overall we observe that except for the role of patent protection, manufacturing innovation expenditure determinants found in the base model appear to be robust to the use of weights and different databases. In the case of services, the most robust determinants of the decision and extent of innovation expenditure are size and public financial support. Significant determinants, such as exporting, patent protection and cooperation for R\&D are sensitive to the use of weights or the inclusion of older or newer data. Finally, looking at KIBS and traditional services, adding the $4^{\text {th }}$ and $7^{\text {th }}$ survey with weights generates similar results to the weighted version of the $5^{\text {th }}$ and $6^{\text {th }}$ surveys, indicating the same potential weaknesses of the results found in the base estimations. 


\section{References}

Aghion, P., Bloom, N., Blundell, R., Griffith, R. and Howitt, P. (2005) Competition and Innovation: An inverted U relationship. Quarterly Journal of Economics, 120(2): 701-728.

Alvarez, R. and G. Crespi (2011): "Do Financial Constraints explain Innovation Shortfalls? New Evidence from Chile," mimeo, University of Chile and BID.

Acs, Z. and Audretsch, D (1988) Innovation in large and small firms: an empirical analysis. The American Economic Review. 78 (4): 678-690.

Banco Central (2012) Boletín Mensual Abril 2012. Banco Central de Chile:Santiago.

Benavente, J.M. (2006), "The role of research and innovation in promoting productivity in Chile", Economics of Innovation and New Technology Vol15 (4/5) June-July, pp 301315.

Bernard, A. \& Jensen, B. (1999), "Exceptional exporter performance: cause, effect, or both?". Journal of International Economics, 47(1), 1-25.

Boschma, R. (2005) Proximity and innovation: a critical assessment. Regional studies 39(1): $61-74$

Bravo, C., Benavente, J.M. and A. Gonzalez (2011), "Innovation, Exports, and Productivity: Learning and Self Selection in the Chilean Case", Mimeo, Department of Economics, University of Chile.

Cainelli, G., Evangelista, R. and M. Sanova (2006). "Innovation and Economic Performance in Services: A Firm-Level Analysis," Cambridge Journal of Economics 30 (3): 435-458.

Cohen, W. and Levinthal, D. (1990) Absorptive capacity: a new perspective on learning and innovation. Administrative Science Quarterly. 35(1): 128-152.

Crepon, B., E. Duguet and J. Mairesse (1998). "Research, Innovation and Productivity: An Econometric Analysis at the Firm Level." Economics of Innovation and New Technology 7(2): 115-158.

Crespi, G and P. Zúñiga (2011), "Innovation and Productivity: Evidence from Six Latin American Countries". World Development 40(2): 273-290.

Daude, C. and Eduardo Fernández-Arias (2010). "On the Role of Aggregate Productivity and Factor Accumulation in Economic Development in Latin America and the Caribbean. IDB Working Paper Series 131. Washington, DC. 
Department of Trade and Industry (2007). "Innovation in Services". DTI Occasional paper.

Drejer, I. (2004). "Identifying innovation in surveys of services: a Schumpeterian perspective". Research Policy, 33(3), 551-562.

Eickelpasch, A. and Vogel, A. (2009), "Determinants of Export Behavior of German Business Services Companies". DIW Berlin Discussion Papers, 876.

Gallouj, F. and M. Savona (2009). "Innovation in Services: A Review of the Debate and a Research Agenda," Journal of Evolutionary Economics, 19(2): 149-172.

Gustavsson, P. and P. Karpaty (2011). "Service-sector competition, innovation and R\&D," Economics of Innovation and New Technology 20(1): 63-88.

Hertog, P. den (2010) Managing service innovation. Firm level dynamic capabilities and policy options. Dialogic Innovatie and Interactie:Utrecht.

Huber, F. (2012) Do cluster really matter for innovation practices in information technology? Questioning the significance of technological knowledge spillovers. Journal of Economic Geography. 12: 107-126.

Iacovone, L. Mattoo, A. and Andrés Zahler (2012), "Trade and Innovation in Services: A Study of Chile". Mimeo.

IDB (2010). Development in the Americas: The Age of Productivity: Transforming Economies from the Bottom Up. Washington, DC, United States: Inter-American Development Bank, Palgrave McMillan.

Leiponen, A. (2012). "The benefits of R\&D and breadth in innovation strategies: a comparison of Finnish service and manufacturing firms, "Industrial and Corporate Change 21 (5): 1255-1281.

Llisterri, J. and García-Alba, J, (2008) High-growth SMEs in Latin American emerging economies. IDB Technical Note. Social sector science and technology division. No. IBDTN-133.

Malerba, F. and Orsenigo, L. (1997) Technological regimes and sectoral patterns of innovative activities. Industrial and Corporate Change. 6(1): 83-117.

MINECON -Ministerio de Economía, Fomento y Turismo de Chile-(2008) La dinámica empresarial en Chile (1999-2006). Foro Pro-Innovación: Santiago.

OECD, E., 2005. Oslo Manual-Guidelines for Collecting and Interpreting Innovation Data. EUROSTAT, Luxembourg. 
OECD (2009) OECD Territorial Reviews: Chile. OECD:Paris.

Pires, C.P., Sarkar, S. and L. Carvalho (2008), "Innovation in services-how different from manufacturing?” The Service Industries Journal, 28(10), 1339-1356.

RICYT; OAS; CYTED; COLCIENCIAS; OCYT (2001) Standardization of indicators of technological innovation in Latin American and Caribbean countries: Bogota Manual.

RICYT; OAS; CYTED; COLCIENCIAS; OCYT [Accessed online May, 2012]

Santamaria, L. Nieto, N.J. and I. Miles (2012). "Service Innovation in Manufacturing Firms: Evidence from Spain," Technovation, 32(2): 144-155

Savignac, F. (2008). "Impact Of Financial Constraints On Innovation: What Can Be Learned From A Direct Measure?," Economics of Innovation and New Technology, vol. 17(6), pages 553-569.

Shefer, M. and Frenkel, A. (2005) R\&D, firm size and innovation: an empirical analysis. Technovation 25: 25-32

Sirilli, G. and R. Evangelista (1998), "Technological innovation in services and manufacturing: results from Italian surveys". Research Policy, 27(9),881-899.

Storper, M. and Venables, A. (2004) Buzz: face-to-face contact and the urban economy. Journal of Economic Geography. 4: 351-370.

Tacsir, E. (2011) Innovation in Services: the hard case for Latin America and the Caribbean. IDB Discussion paper. Capital markets and financial institutions division. No. IDB-DP203.

Tether, B. (2005). "Do Services Innovate (Differently)?: Insights from the European Innobarometer Survey,” Industry and Innovation, 12(2): 153-184..

Tether, B. and J. Howells (2007), "Changing Understanding in Innovation in Services", Chapter 2 in DTI, Innovation in Services.

Vahter, P. and J. Masso (2011). "The Link between Innovation and Productivity in Estonia's Service Sectors," William Davidson Institute Working Paper Number 1012, March. 